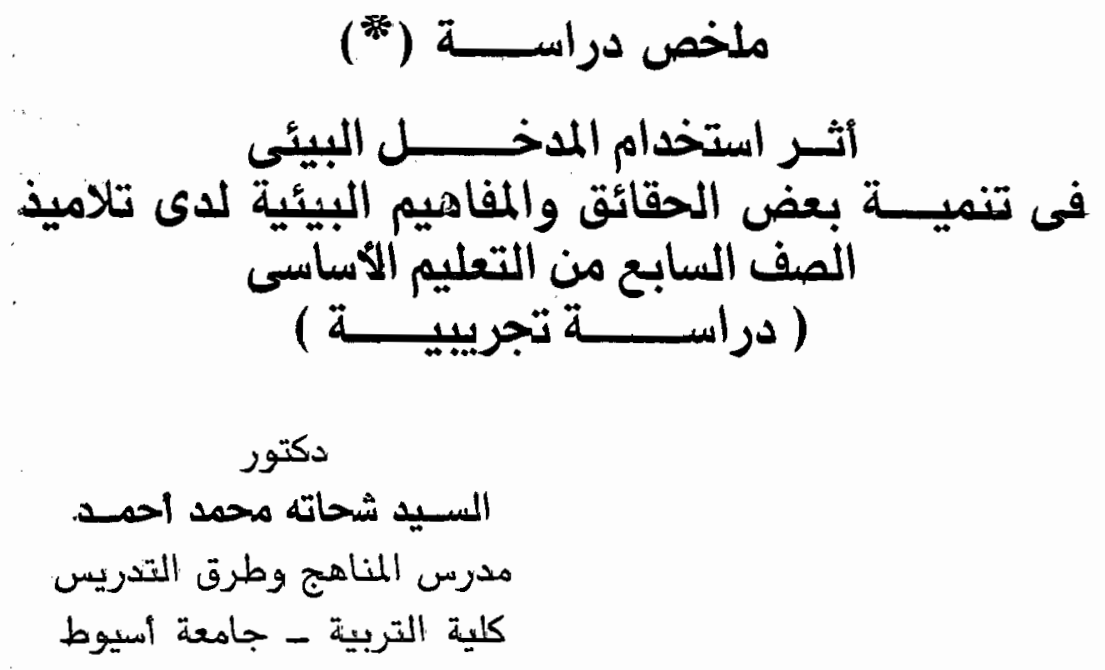

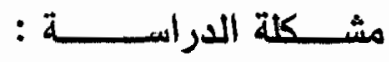

1 ـ ما البرنامج المقترح في التربية البيئية لتلاميذ الصف المابع من

التحليم اللأساسى : المجح

r ما محتوى برنامج " أثر الانسان على البيئة ) ؟

r - ما مدى فعالية استخدام المدخل البئئى فى تخمية بعض المقائق والمفاهيم البيئية لدى تلاميذ الصف المسابع من التعليم الأساسى ؟

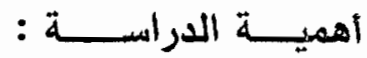

لقد أهبح موضوع تفايعل البيئة الطبيعية في مجال التعليم من

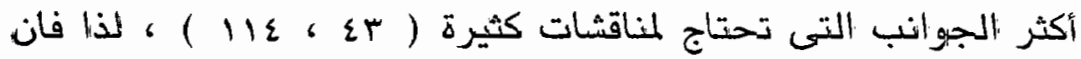

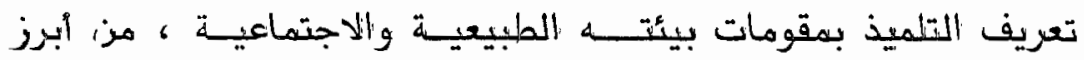

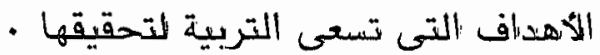

ويتزايد فى اللوقت الحاضر اللاعتراف بالدور الذى يمكن الن تلعبه

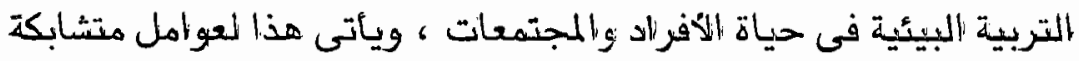

م تطلب الدراسة الكاملة من الباحث شخصيا أو بالبريد ) 
تتعلق بعلاقة الانسان زمثقوملت بيئته ، (

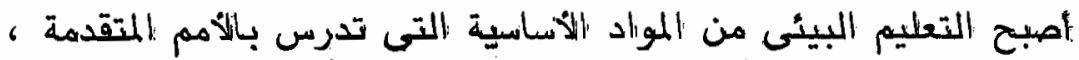

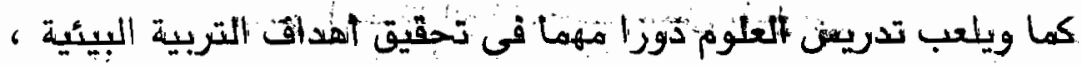

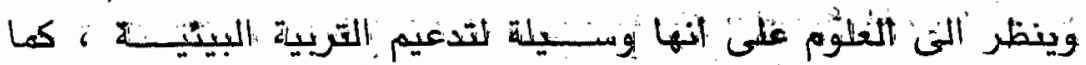

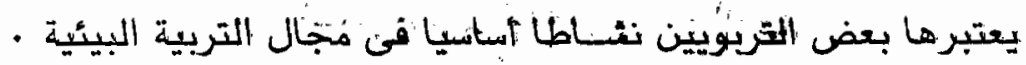

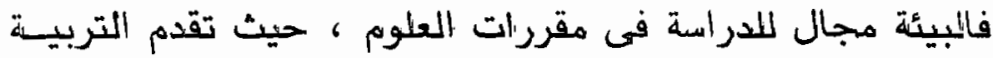

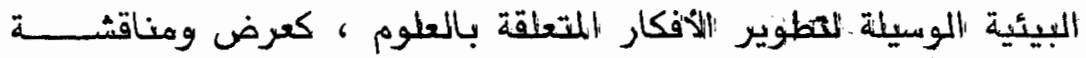

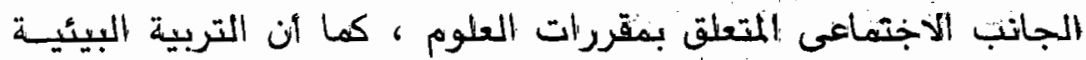

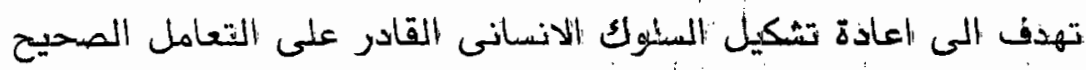

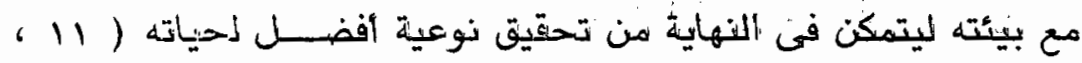

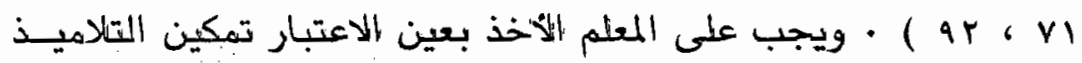

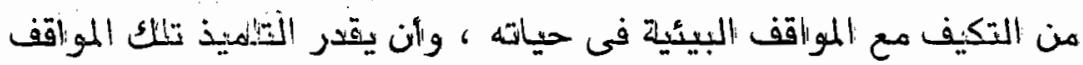

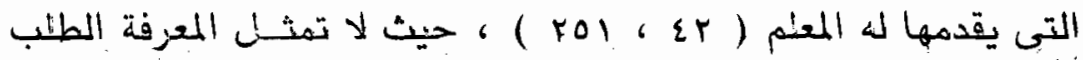

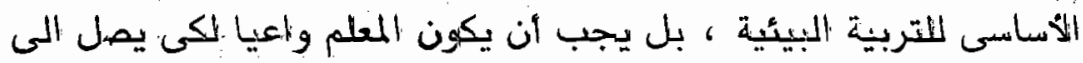

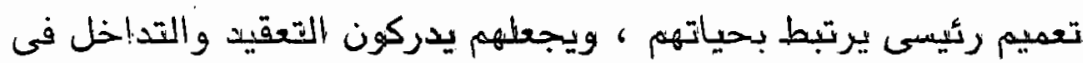

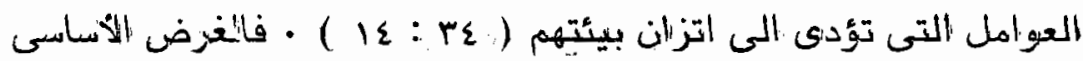

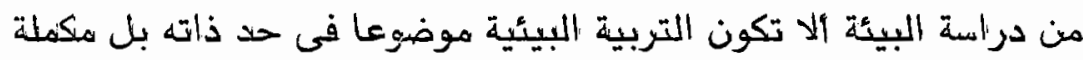

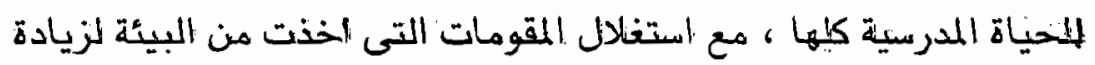

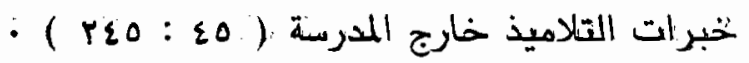

ولقد اتبع الباحث المدخل البيئى ، للوقوف على مدى فعاليته في المئي

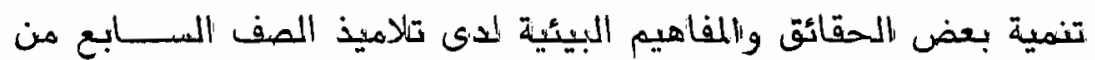

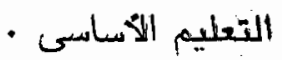

ولكن مداخل التربية ألبيئية في التحليم العام ، تتمثل فيى ثلاثثة

$$
\begin{aligned}
& \text { مداخل أساسية هى : ( } \\
& \text { المدنخ الأول : }
\end{aligned}
$$

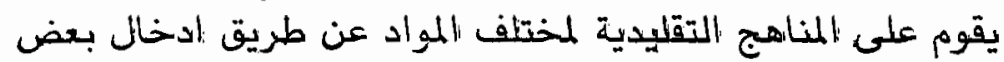

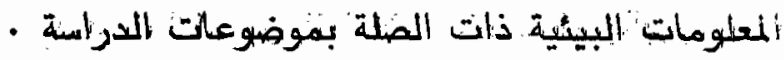


ويعتمد ذلك أساسا على جهوت الموجه والمعنم في طريقة التتوجيه

والتدريس

\section{: المدخل الثانى}

ويتناول إعداد وحدة أو فمل أو جزء عن البيدئة ، يصمسمب تصميما

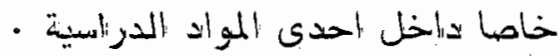

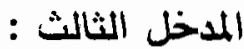

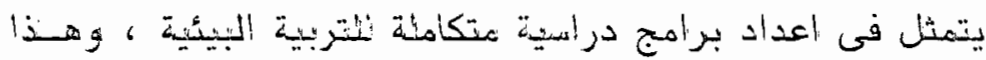

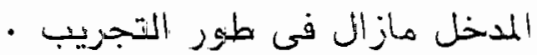

والمدخل الأول قائم الى حد ما ، وهو الأكثر سهولة ، حيث يربط التيط

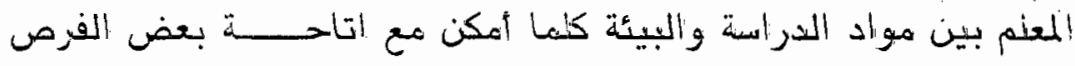

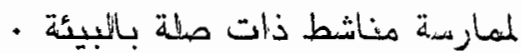

أما المدخل الثانى فقد أخذت بهـ العديد من المناهج وبخاصة مناهج

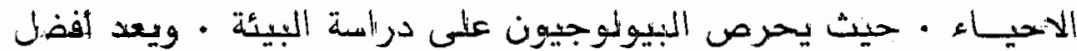

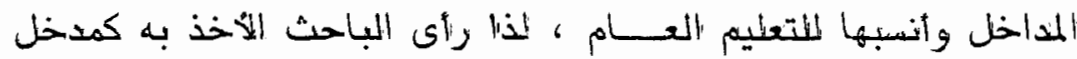

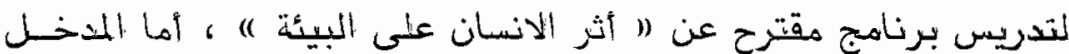

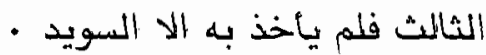

\section{وقد تطلب ذلك : 2 - 2}

1 - اعداد برنامج فى اللتربية البيئية لتلاميذ الصف السابع من التعليم

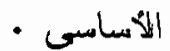

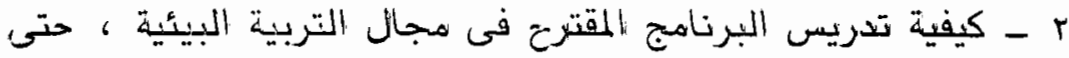

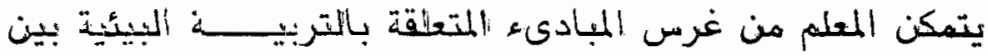

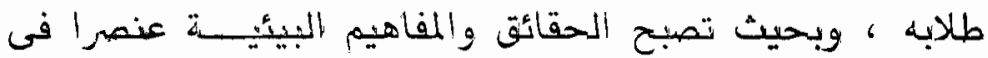

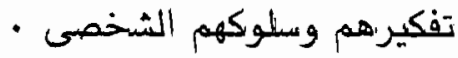


r - الوقوف على مدى فعالية استخدام المدخل البيئى ، على تحصيني

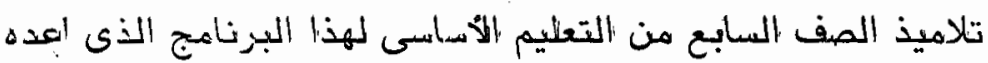

الباحث

ومن هنا اتخذ الباحث :

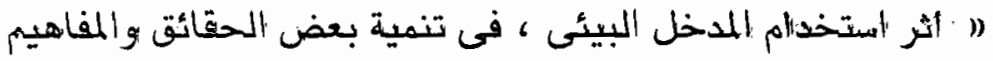

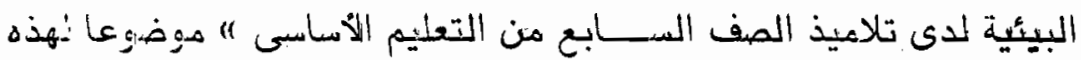

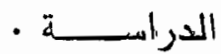

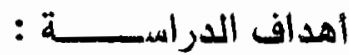

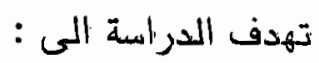

1 - اعداد برنامج في التربية البيئية لتتلاهيذ الصف السابع مَن ألتعنيم

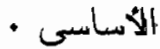

$$
\text { r - بـتخدام المدخل البيئى في تدريس البرنامج المقترح • }
$$

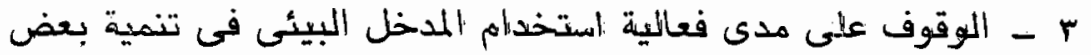

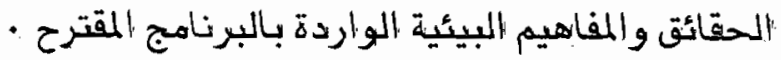

- الكائلة التى تحاول الدراسة الاجابة عنها :

يمكن تحديد مشكلة الدراسة الحالة على النحو التالى :

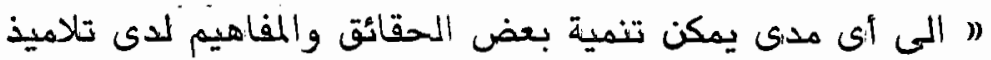

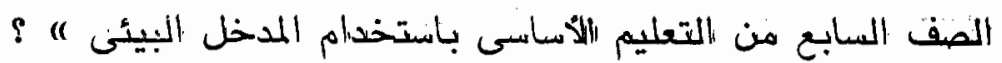

\section{ويرتبط بهذه المشكلة الأسئلة التالية :}

1 ـ ما البرنامج المقترح فى التربية البيئية لتتلاميذ الصف السابع من

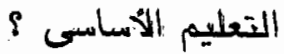

r - كيف يمكن استخدام المدخل البيئى فى تدريس البرنامج المقترح نتلاهيذ الصف السابع من التعليم الأساسى ؟ 
r - ما مدى فعائية استخدام المدخل البيئة ، في تينعية بعض الحقائق

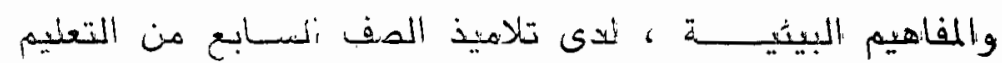

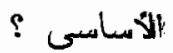

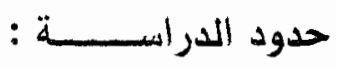

تقتصر هذه الدر اسة على :

1 - بعض تلاميذ الصف السابع من التعليمي الأساسى بمدرسة اللاعدادية

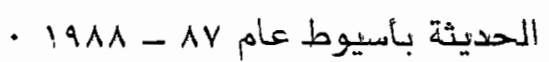

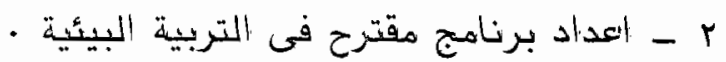

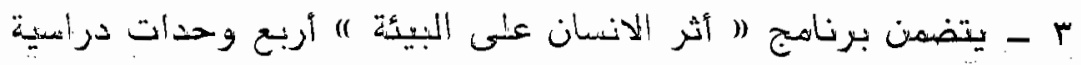
:

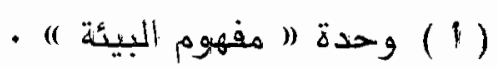

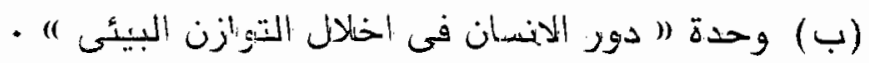

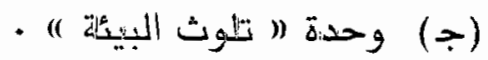

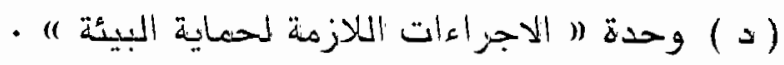

( ) (المصطلاحات

:

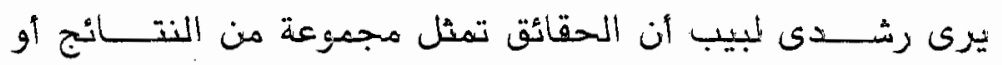

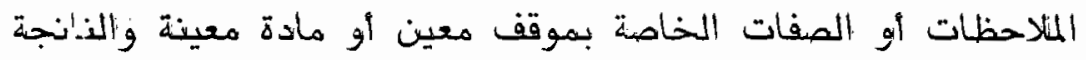
عن الملاحظة والاحساس (

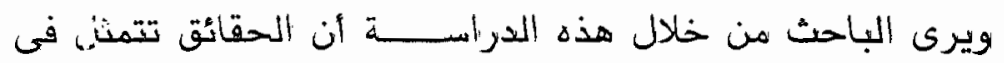

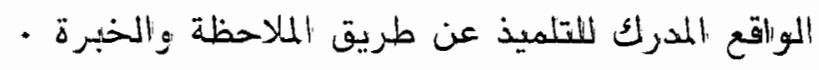

: ب المفاهيم

يرى رشدى لبيب أن المفهوم عبارة عن تجريد العناصر المثــركة 
بين عدة مواقف أو أشياء ، وعادة يعطى هذا التجريد امما ؤو عنوأنا أو رمزا (

وبعتبر أحهد خيرى كاظم وسعد يس المفهوم بأنه عبارات أو رموز

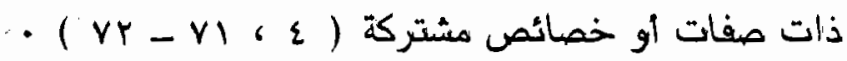

اما أحمد زكى صائح فيرىى أن المفهوم عبنازة عن الستخجابة الفظيـة

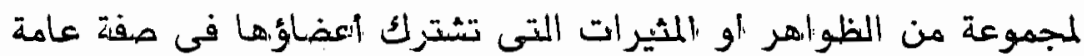
- (rya 6 1)

لذا فان الباحث يربى من خلال هذه الدراسـة بان المفهوم يمثل

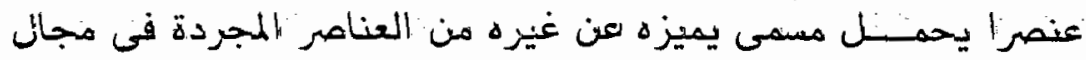

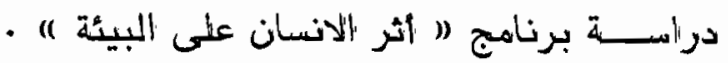

\section{اجراءات الدراســــة}

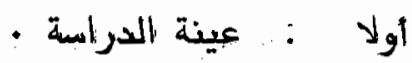

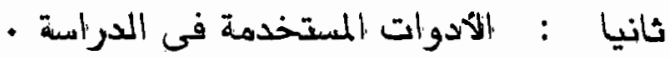

ثالثا : : اعداد برنامج " أثر الانسان على البيئة " .

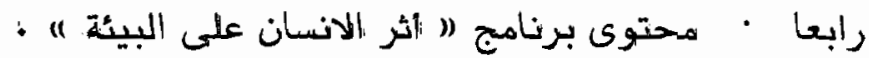

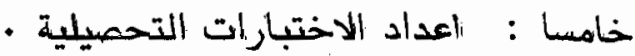

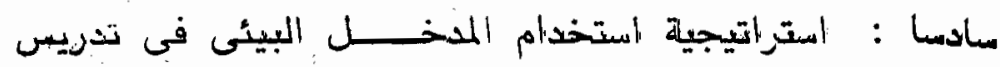

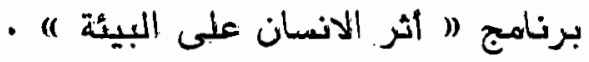

سابعا : تطبيق برنامج " أثثر الانسان على البيئة " " ل ثامنا : المعالجة الاحصائية : المانية تاسعا : النتائج ، والهم التوصيات

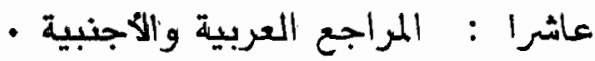
وفيما يلى تحليل لجوانب اجراءات الدراسة : 


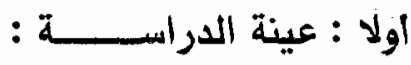

قام الباحث باختيار عينة العراســـة بطريقة عشوائية ، لاجزاء

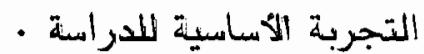

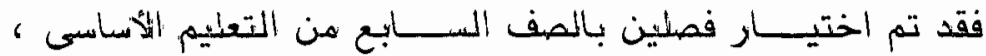

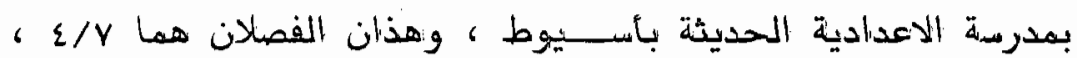

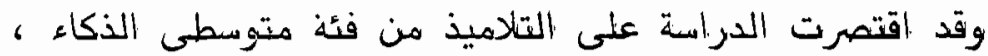

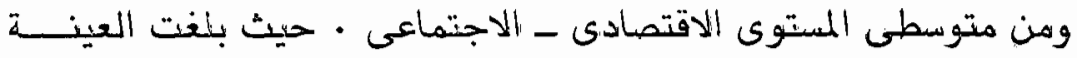

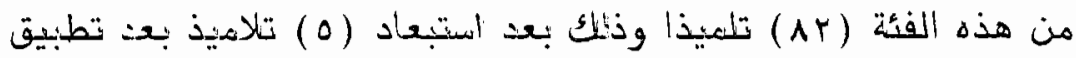

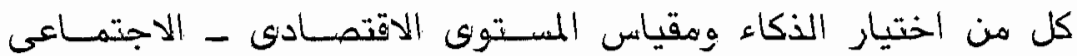

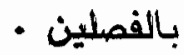

ثانيا : الأدوات المستخدمة فى الدراسة :

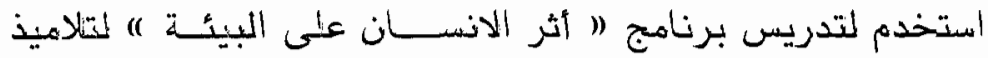

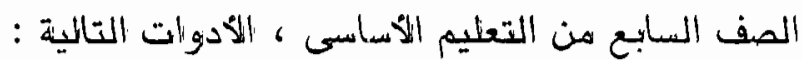

- اختبار الذكاء الاعدادى ، الذ ى أعده السيد محمد خيرى

$$
\text { - (1) ، (v) }
$$

r - بيانات الحالة الاجتماعية - الاقتهصادية الذى أعده قسـم

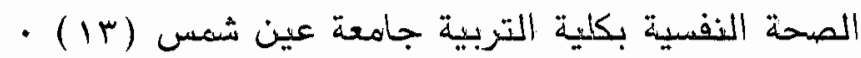

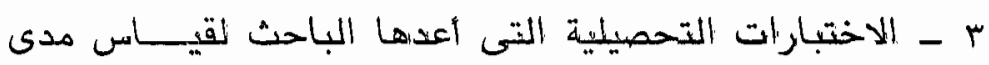

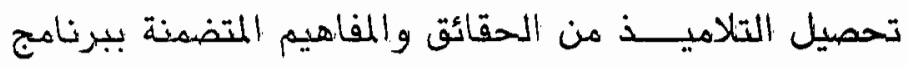

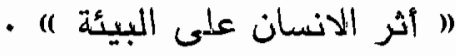

ثالثا : اعداد برنامج (ل أثر الانسان على البيئة ) )

للاجابة عن السؤال الأول من اللأسئاة التتى تحاول التراسة اللاجابة عنهـ 
" ما البزنامج المقترح فى التربية البيئية لتلاميذ الصف السابع هن التعليم الأساسى ) ؛

قام الباحث باعداد برنامج فى التربية البيئية ، وقد تطلب ذلك :

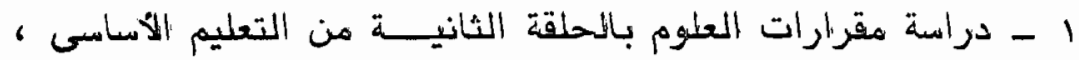

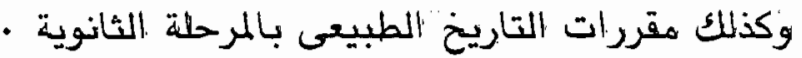
r - هن خلال هذه الدراسة ، أمكن الوقوف على أن الوحدة الخامسة

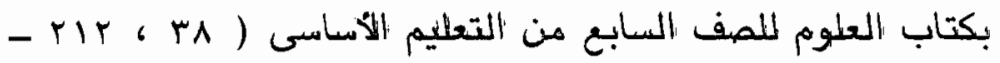

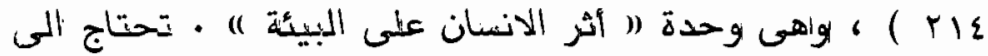

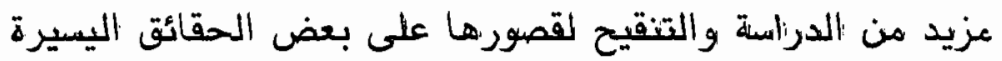

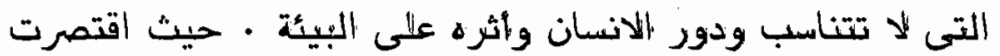

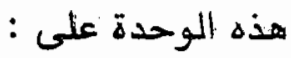

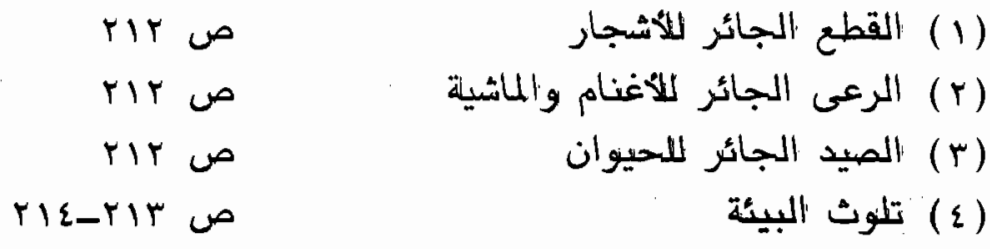

r - ـ أى الباحث تحويل موضوع " أثر الانسان يعلى ألبيئة ) بوصفه

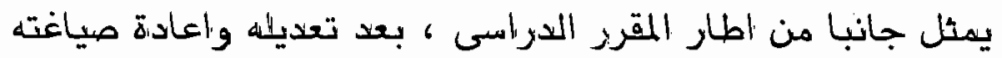

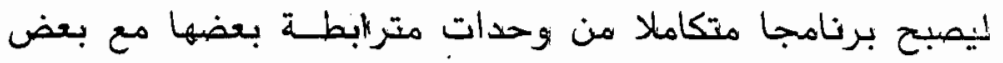

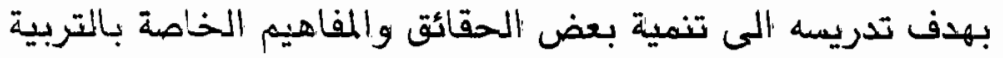

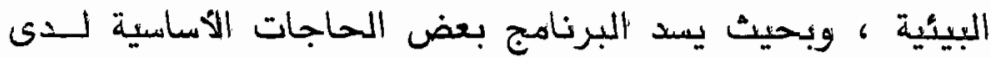

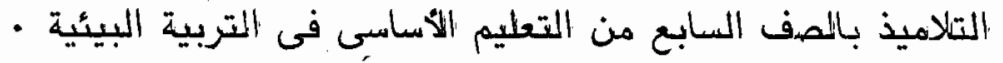

ع - حددت الأهداف الملوكية للبرنامج فيما يلى ( ) :

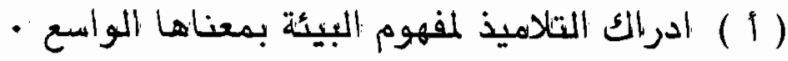

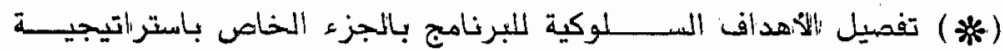

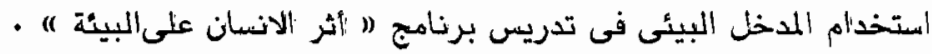


(ب) تبصير التلاهيذ ، بمدى تأثر البيئات المختلفة بعضها ببعض .

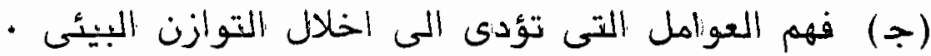

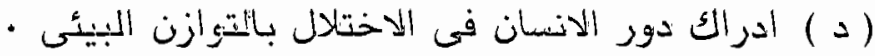

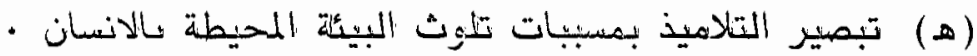

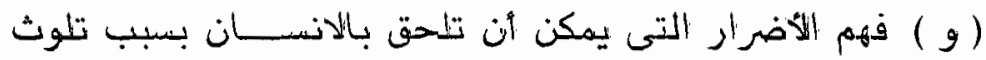

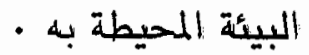

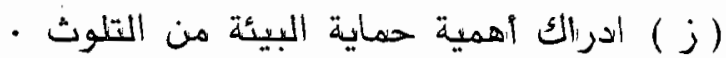

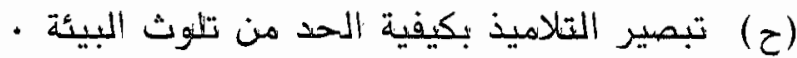

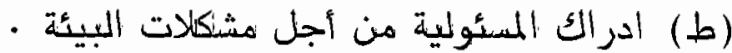

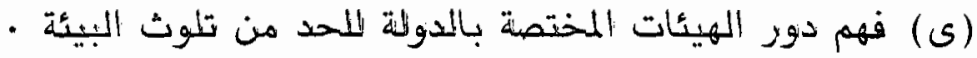

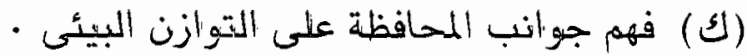

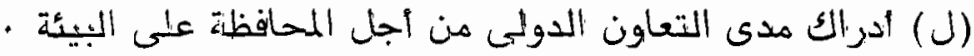

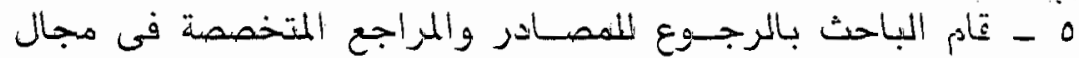

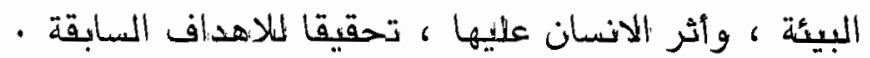

1 - راعى الباحث المعايير التالية عند بناء برنامج أثر الانسـان على :

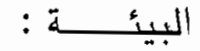

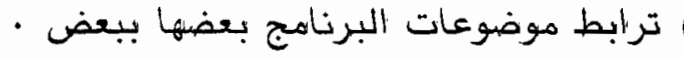

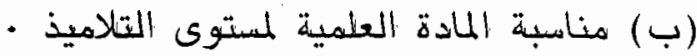

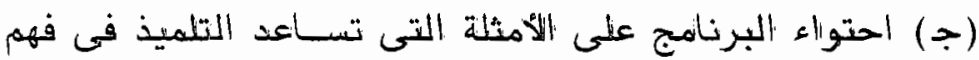

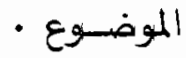

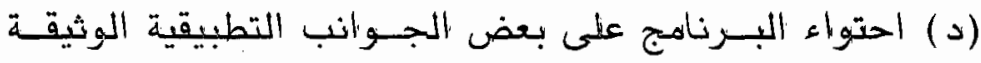

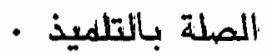

(ه) احتواء البرنامج على الوسائل التعليهية التى تساعد على التى

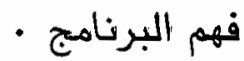

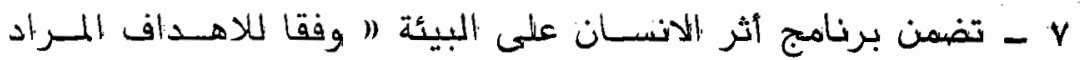

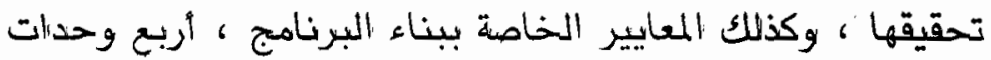

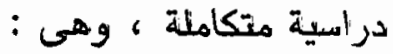




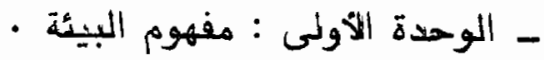

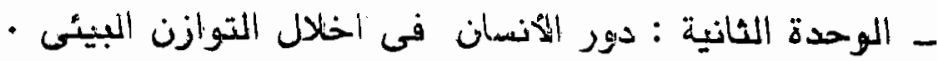

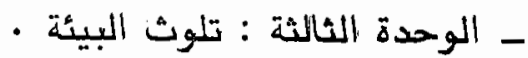

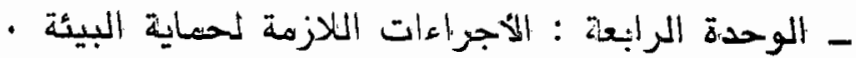

رابعا : محتوى برنامج (ا أثر الانسان على البيئة ) (مثرة) )

خامسا : اعداد الاختبارات التحصيلية :

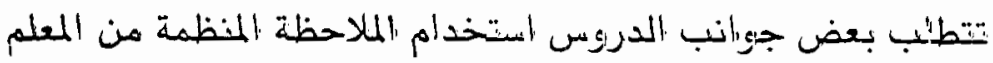

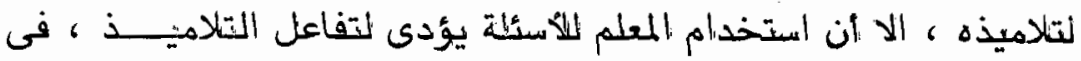

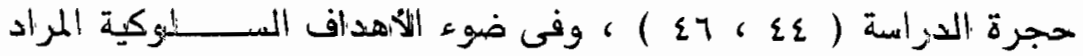

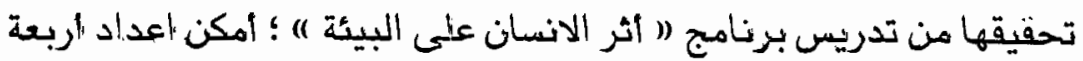

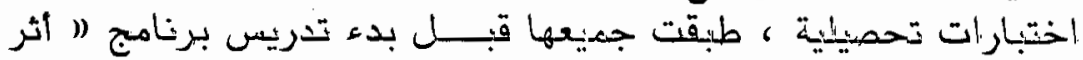

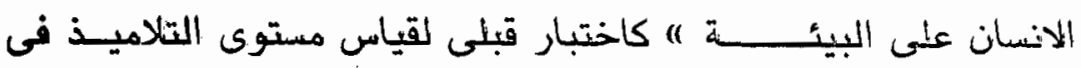

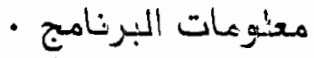

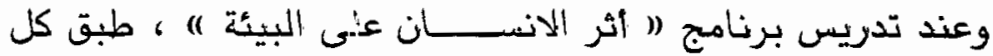

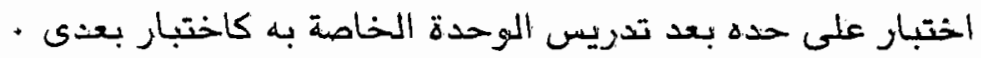

وقد تطلب اعداد الاحتبارات : 1

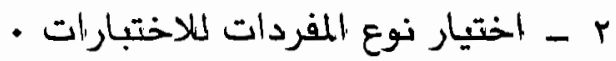

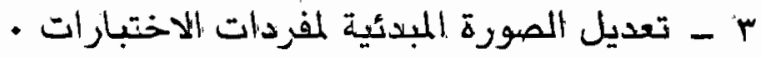

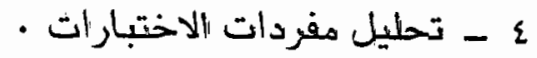
وفيما يلى تحليل لجوانب من الاختبار ات : ـ - تحديد الهدف من الاختبارات :

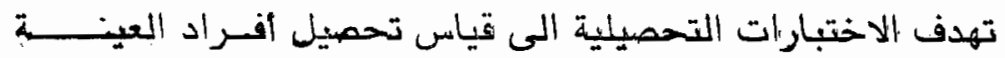

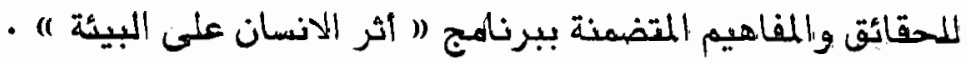


r - تحديد نوع المفردات للاختبارات :

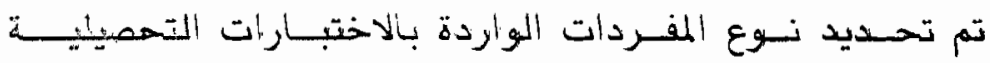
فى ضوء :

- الأهداف المراد تحقيقها من خلال تدريس البرنامج ·

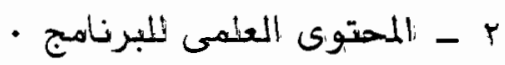

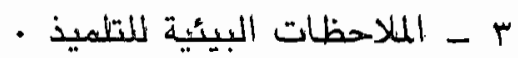

r ـ تعديل الصورة المبدئية لمفردات الاختبارات :

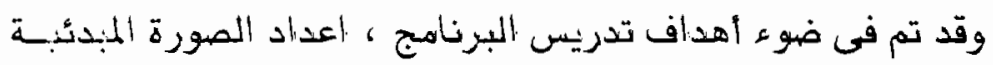

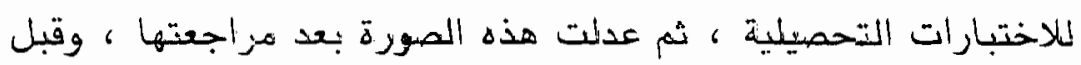

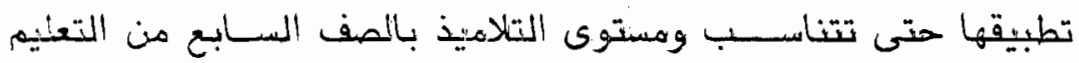
الأساسى ، وبناء على ذلكئك أمكن :

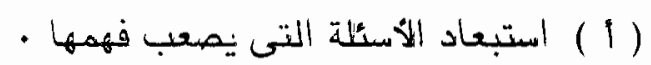

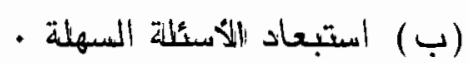

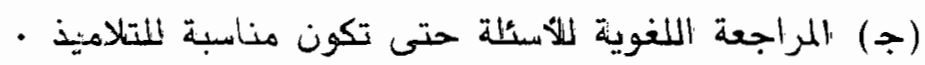

ـ ـ تحليل مفردات الاختبارات : (* )

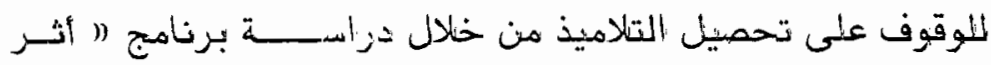

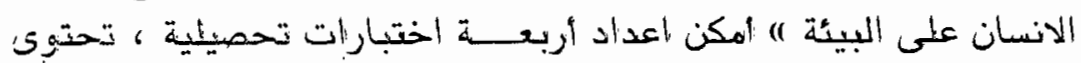

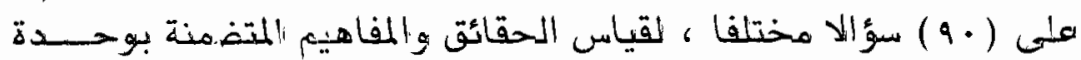

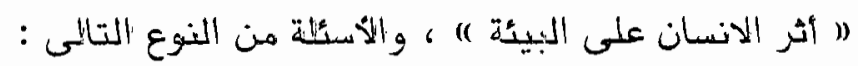

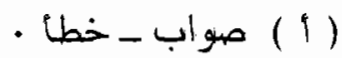

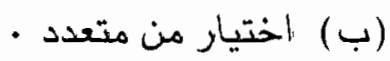

$$
\begin{aligned}
& \text { (ج) المقابلة أو المزاوجة من متود . }
\end{aligned}
$$

ويوضح الجدول (1) توزيع مفردات الاختبارات الأربعة : 


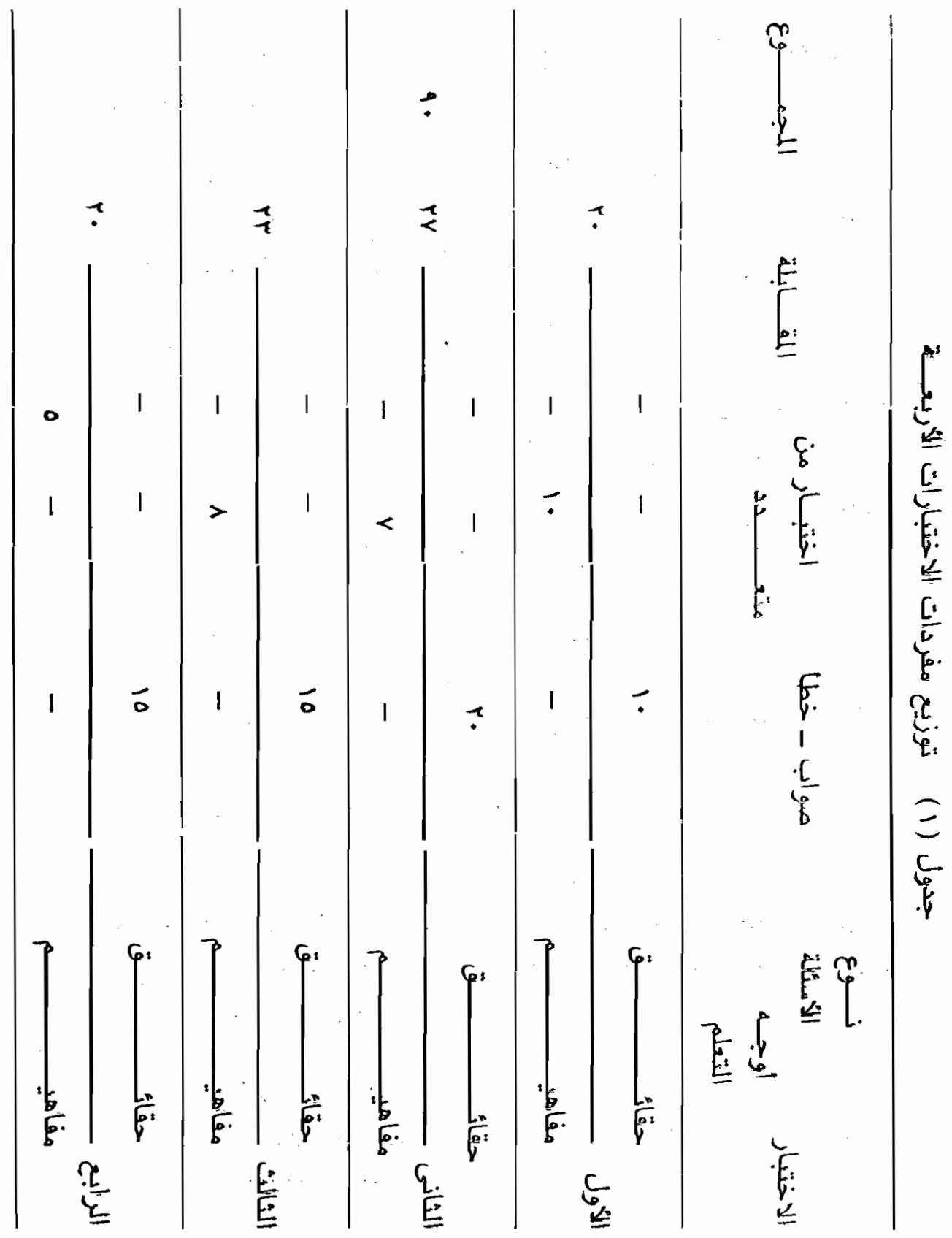




\section{ثانيا : المعالجة الاحصائية :}

للاجابة عنى السؤال الثالث من الأسئلة التى تحاول الدراسة الاجابة عنها وهو : ع اجلة

ما مدى فعالية الستخدام المدخل البيئى ، فى تنمية بعض المقــائق

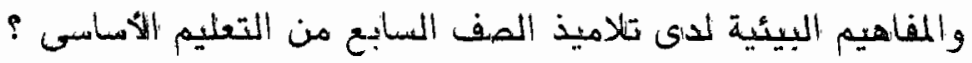

فقد تطب هذا التساؤل وضع الفروضالتالية :

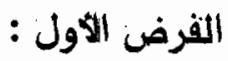

يوجد فرق دال احصائيا بين متوسطى درجات أفراند العينة قبسل العبل

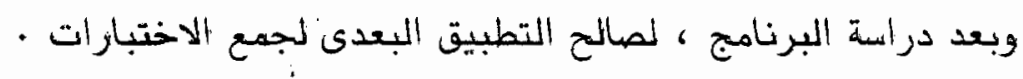

الفرض الثانى : | (الثر

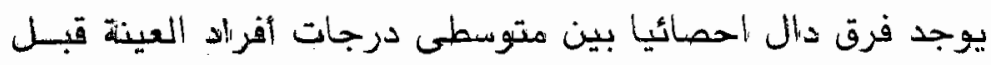

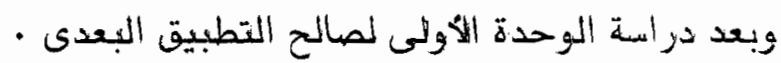

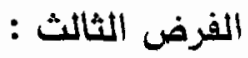

يوجد فرق دال احصائيا بين متوسطى درجات أفراد العينة قبسل

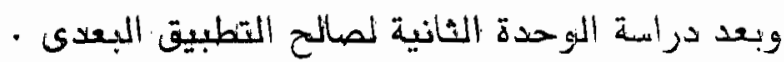

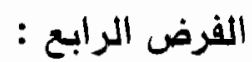

يوجد فرق دال احصائيا بين متوسطى درجات أفرايد العينة قبسل

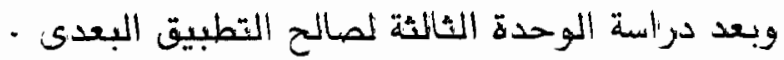

الفرض الخامس : - | (الف

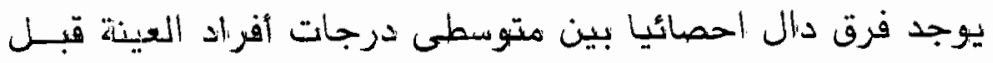

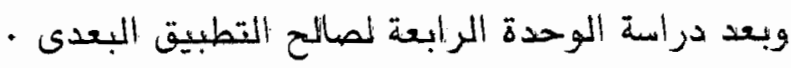




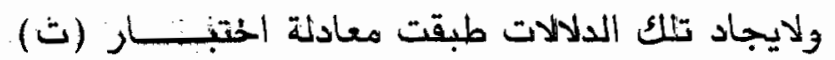

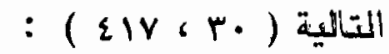

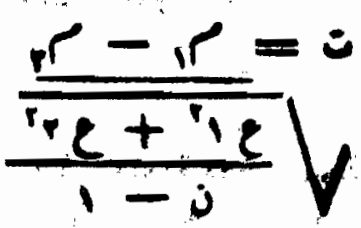

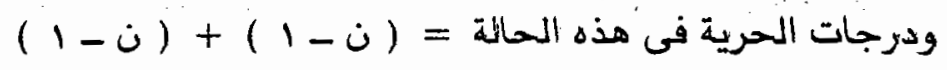$$
r-\dot{r} r=
$$

ولايجاد الانحراف المعيارى أكل من الاختبار القبلى بوالبعبدى يمكن

تطبيق المعادلة التالية :

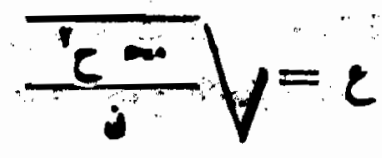

$$
\begin{aligned}
& \text { حيث ع = الالانحراف المعيارى } \\
& \text { - ح } \\
& \text { ن : عدد الحالات }
\end{aligned}
$$

ومن خلال رصد درجات كل من :

$$
\text { - } 1
$$

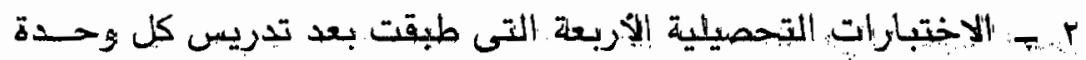

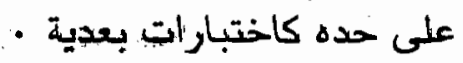

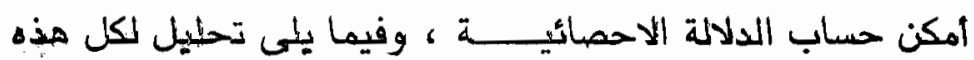

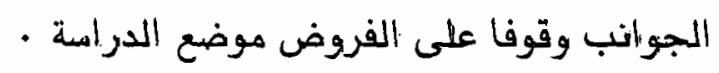

تاسعا : النتائج ، وأهم البوصيات :

1 ـ مدى تحقق الفرض الثأول :

للتحقق من مدى صحة الفرض الأول الذى ينص على أن : " يوجد فرق دال اجصائيا بين متوسطى درجات أفراد العينة قبل ميل 
وبعد دراسة البرنامج ، لصائح التطبيق البحدى في جميع الاختبارات له .

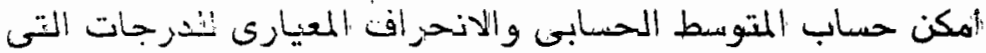

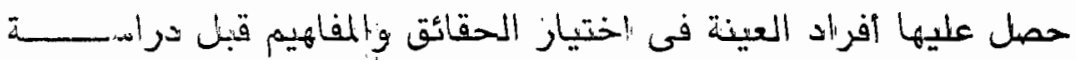

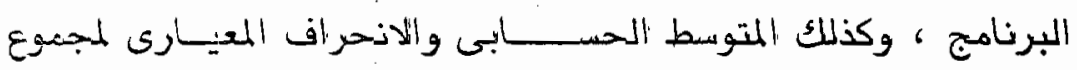

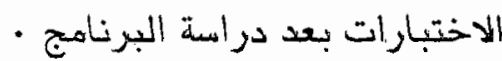

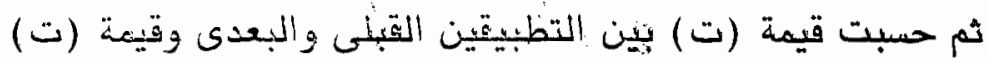

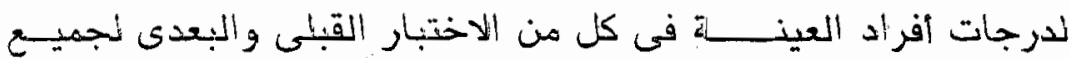
الاختبارنات 


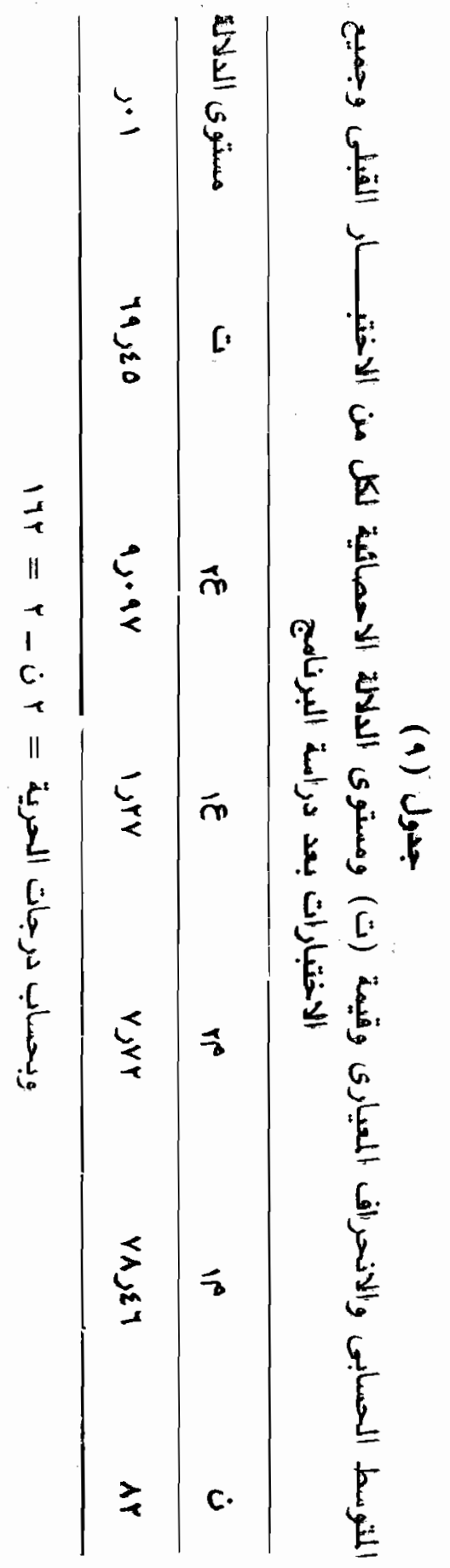




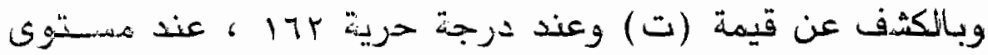

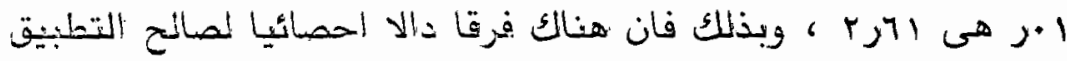
البعدى

وبذلك يمكن القول بأن الفزض اللأول قد تحققى ، دالل يكنى كفائة

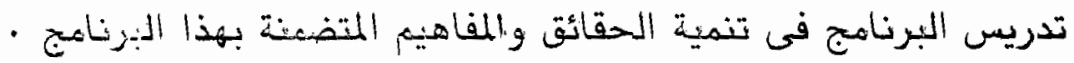
r م مدى تحقق الفرض الثانى : للاتحقق من هدى صحة الفرض النيانى ، الذى ينص على :

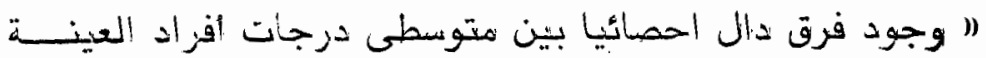

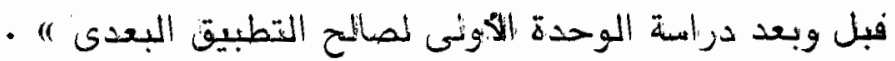
أمكن حســــاب :

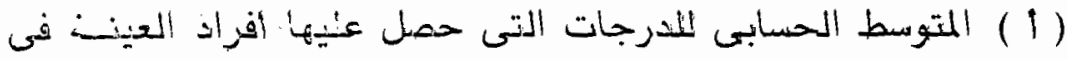

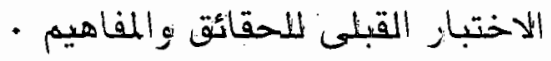

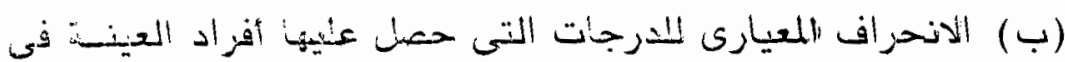

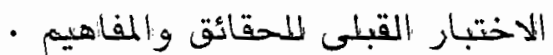

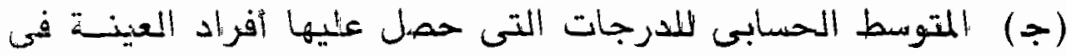

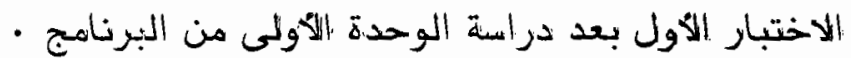

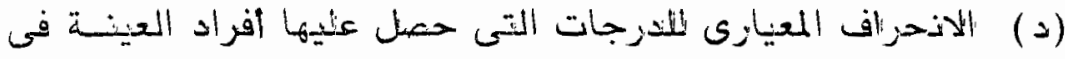

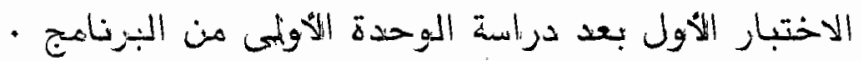
(ه) تيمة (ت) بين التطبيقين القبلى والبعدى للاختبار اللآول .

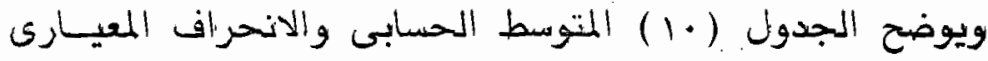
ووقيمة (ت) لدرجات أفراد العينة لكل من الاختبار القبلى ، واللاختباز 


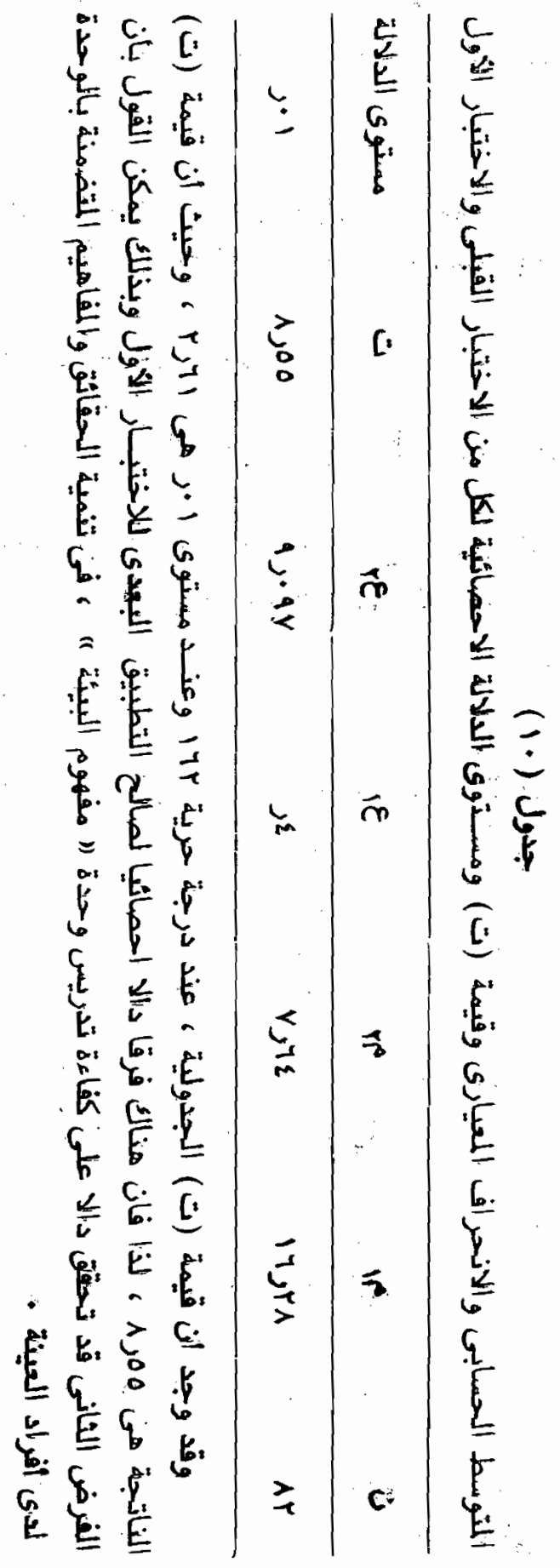


r - مدى التحقق من الفرض الثالث :

للتحقق من صحة الفرض الثالث والذى ينص على :

" وجود فرق دال أحصائيا بين متوسطى درجات أفراد العينة قبل اليل

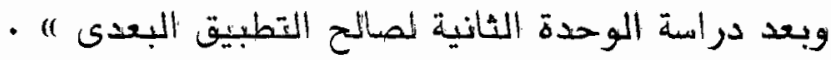

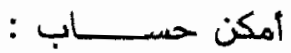

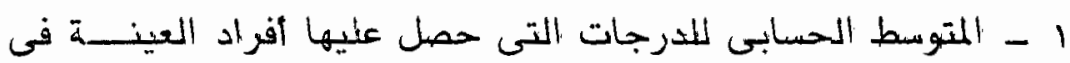

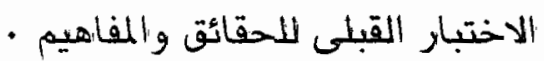

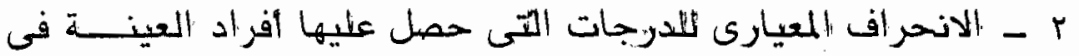

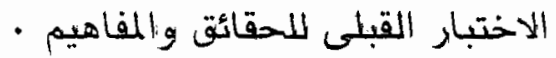

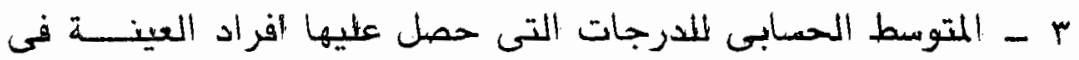

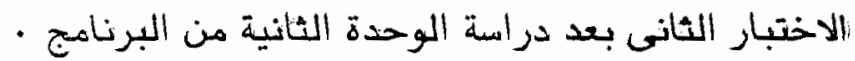

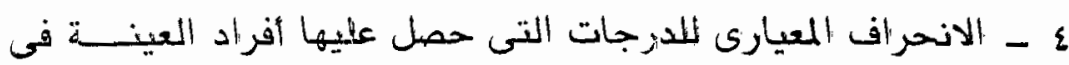

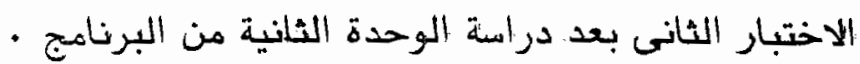

ـ قيمة (ت) بين التطبيقين القبلى والبعدى للاختبار الثانى •

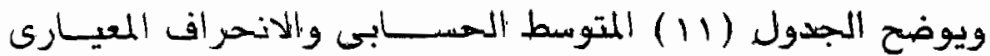

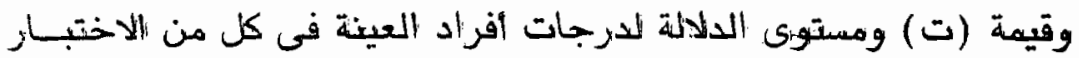

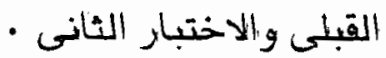




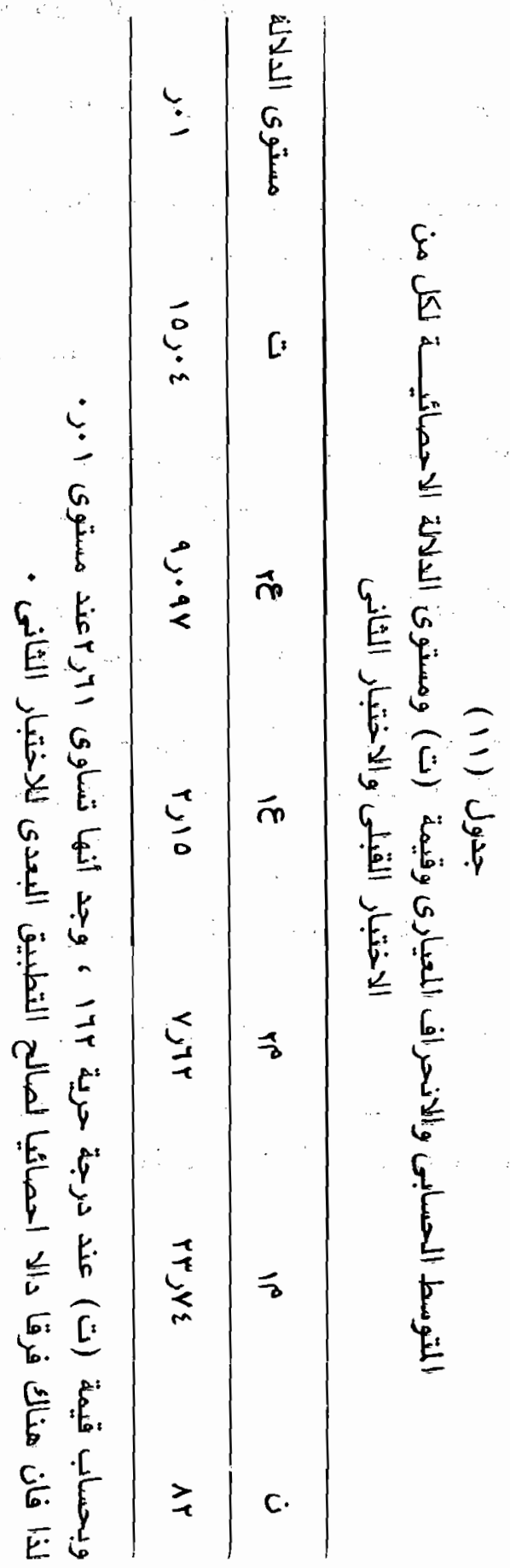


وبذلك يمكن القول بأن الفزض الثالث قد تحقق دالا على كقاءة

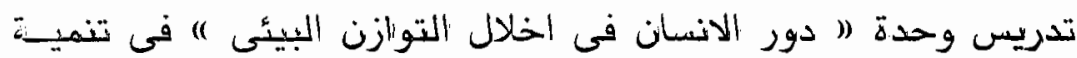

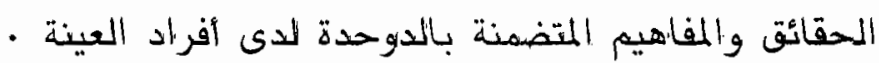

ع - مدى التحقق من مدى صحة الفرض الرابع : والذى ينص على : و

" وجود فرق دال احصائيا بيين متوسطى درجات أفراد العينـة

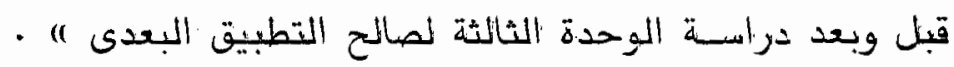

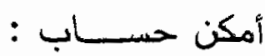

- - المتوسط الحسابى والانحراف المعيارى لدرجات أفرد العينة في المئي

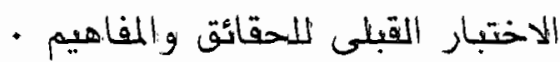

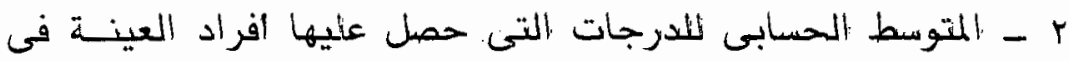

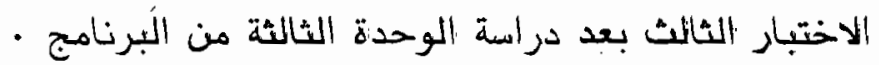

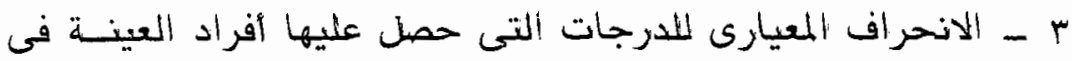

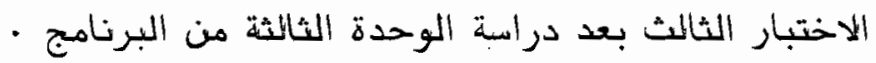

ع - قيمنة (ت) بين التطبيقين القبلى والبعدى للاختبار الثالث .

ويوضح الجدول (r) المتوسط الحسابى والانحراف المعيسارى

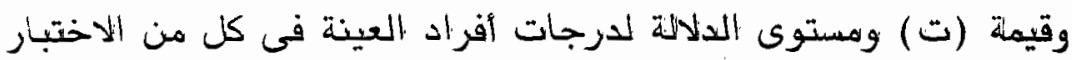

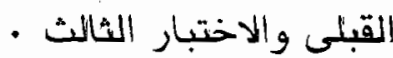




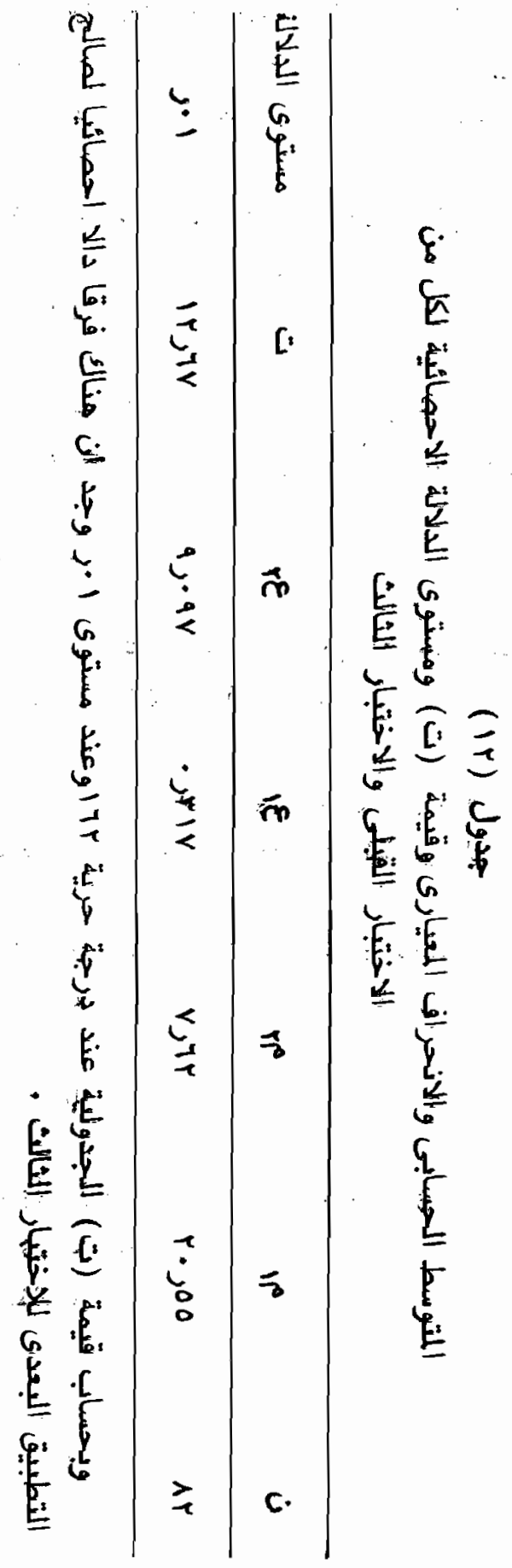


وبذنك يمكن القول بأن الفرض الثالث قد تحقتى دالا على كفاءة تدريس وحدة (" تلوث البيئة ) ، ، في تثنمية الحقائق والمفاهيم المتضمنة

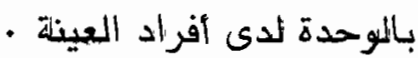

\section{ـ مدى التحقق من الفرض الخامس :}

للتحقق من مدى صحة الفرض الخامس والذى ينص على :

" وجود فرق دال الحصائيا بين متوسطى درجات أفراد العينـة

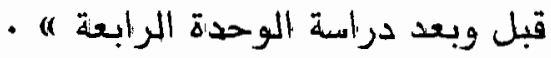

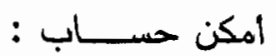

1 ـ المتوسط الحسابي والانحراف المعيارى للدرجات التى حصل عليها

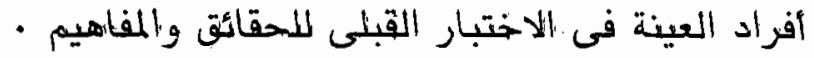

r - المتوسط الحسابى واللانحراف المعيارى اللدرجات التى حصل عنيها

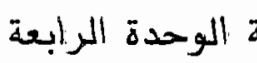

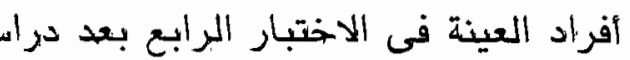

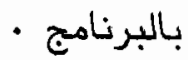

r - قيمة (ت) بين التطبيقين القبلى والبعدى للاختبار الرابع •

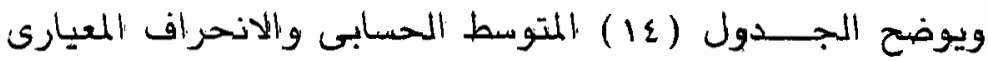

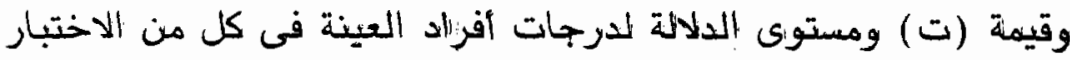
القبلى والاختبار الرابع ومعتوى التول 


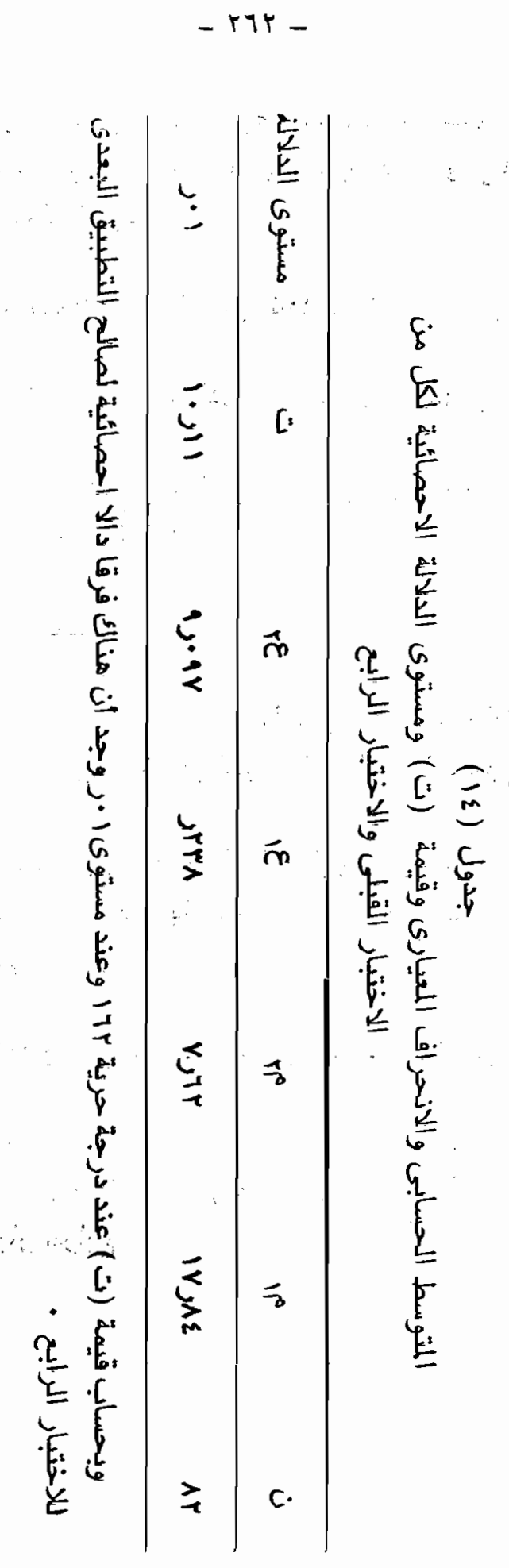




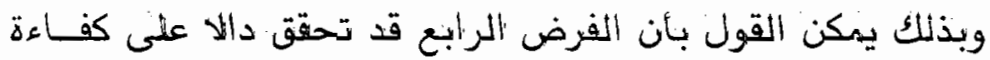

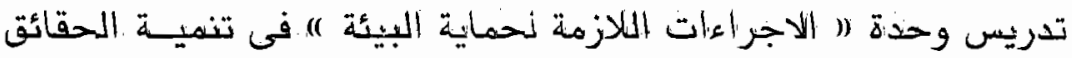

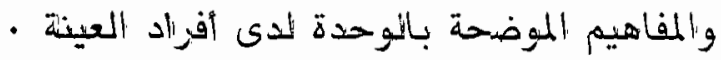

\section{ملخصن النتائج واهم التوصيات :}

تتلخص أهم النتائج التى أهكن التوصل اليها من خلال الدرأسة :

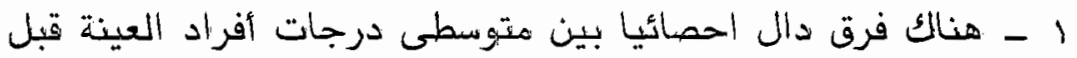

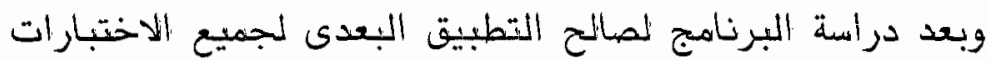

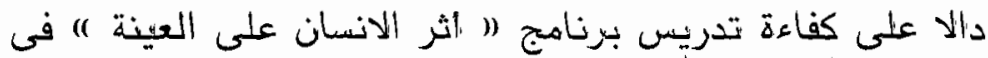

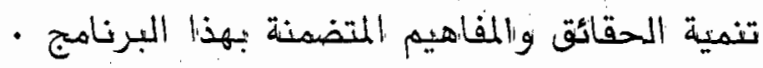

r - وجود فرق دال احصائيا بين متوسطى درجات أفراد العينة قبل

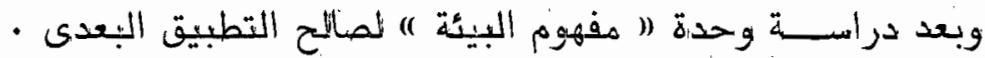

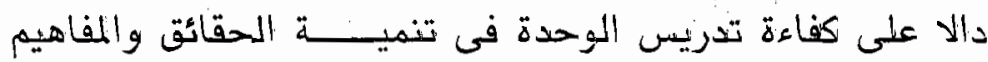

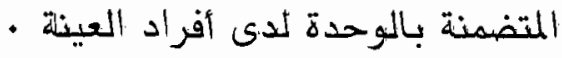

r - وجود فرق دال احصائيا بين متوسطى درجات أفراد العينة قبـلـ الحل

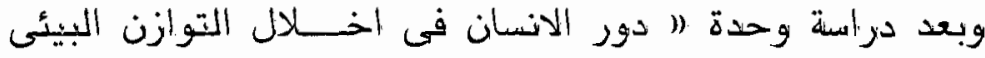

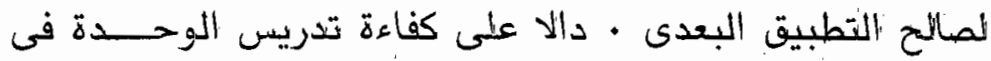

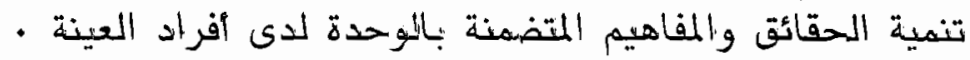

ع - وجود فرق دال إحصائيا بين متوسطى درجات أفراد العينة قبل

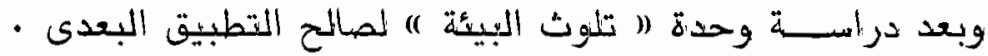

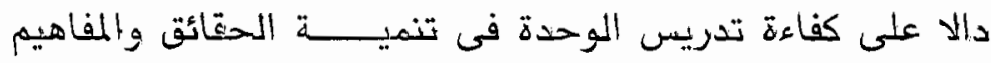

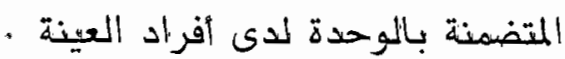

0 - وجود فرق دال احصائيا بين متوسطى درجات أفراد العينة قبل

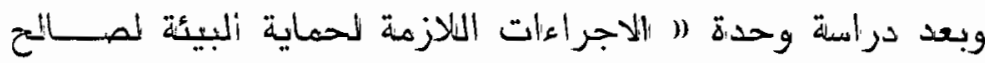

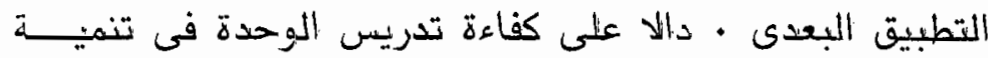

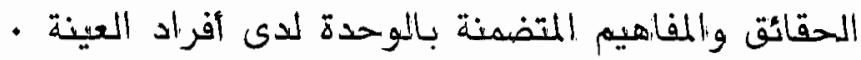

1 ـ من خلال النتائج التى أهكن التوصل اليهـــــ من تطبيق برئاهج 


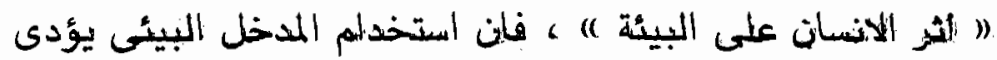

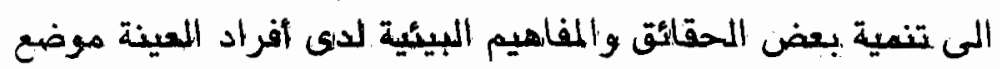

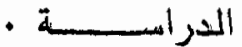

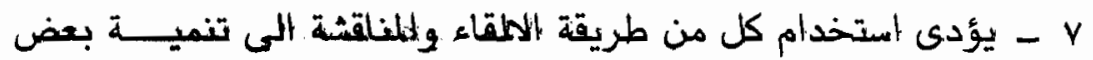

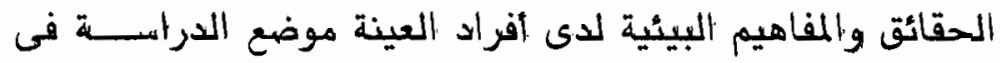

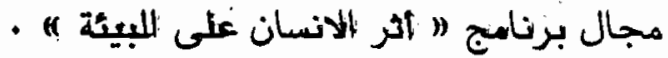

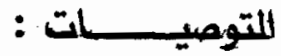

من خلال النتائج التى امكن التومل اليها وكذلك الاطار المنظرى

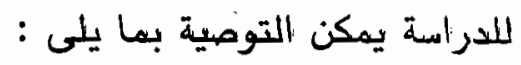
- اجراء بعضض الدراسات الأخرى فى مجال تنمية الحقائق والمفاهيم

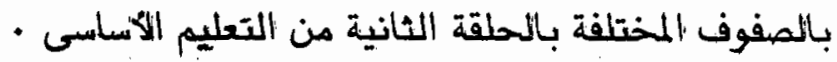

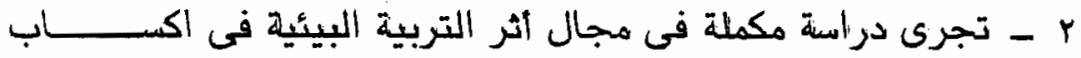

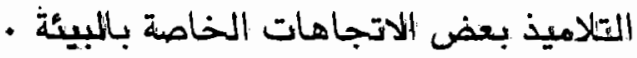

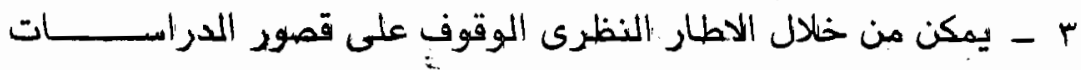

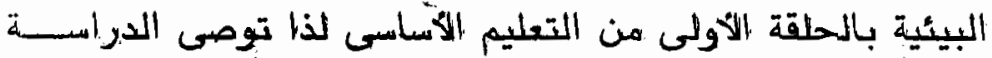

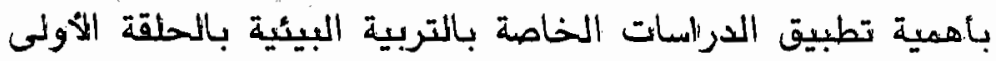

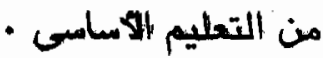




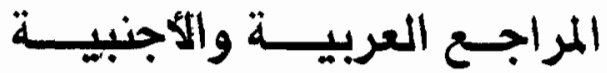

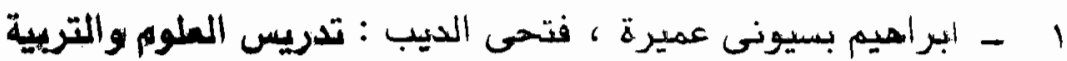

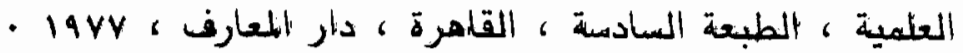

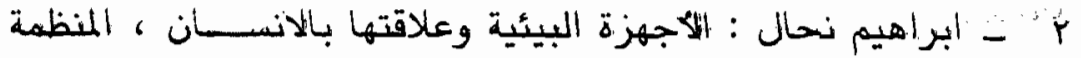

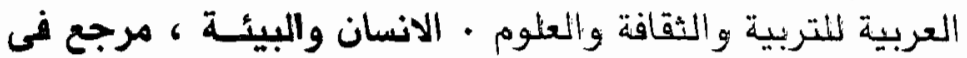

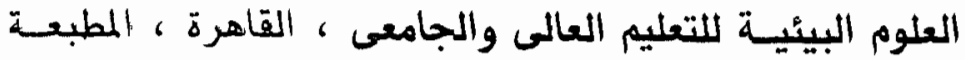

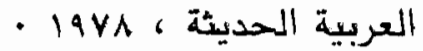

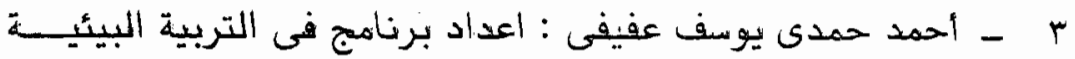

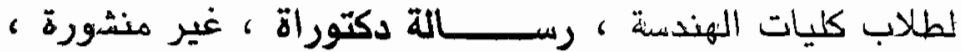

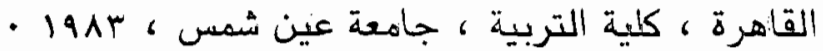

ع - أحمد خيرى كاظم ، سعد يس : تدريس العلوم ، القاهرة ، دار

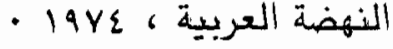

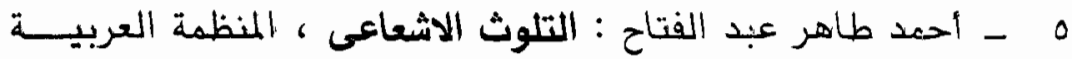

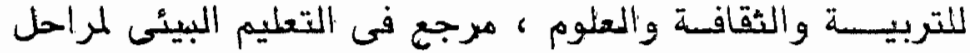

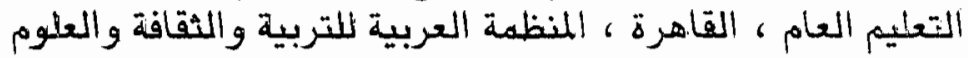

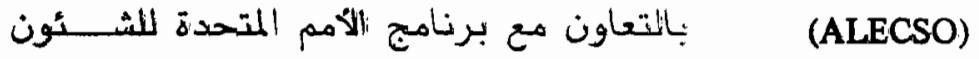
البيئية 19Y4 ، (UNEP)

1 - 1 أحمد زكى صالح : الأسس النفسـية اللتعليم القالثوى ، القاهرة مكتبة النهضة المصرية ، 1901 •

- V

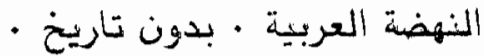

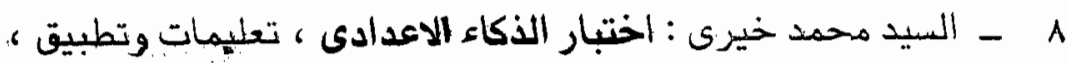

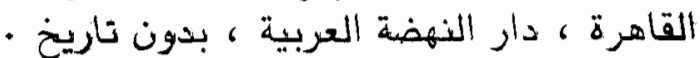

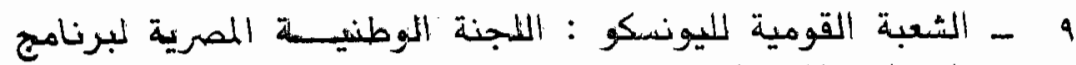

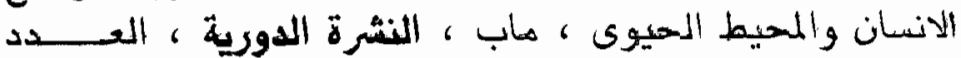


التهول والثانى ، سرس الليان ، مبابع المركز القومى لتعليم - Inar ، الكبار

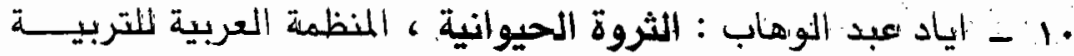

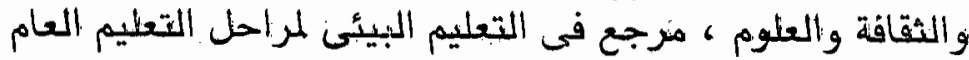

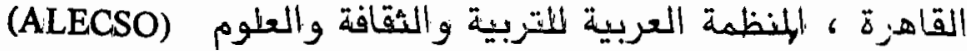

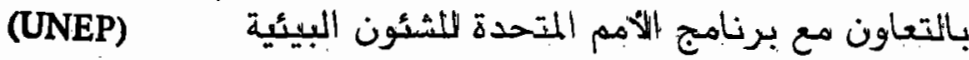

11

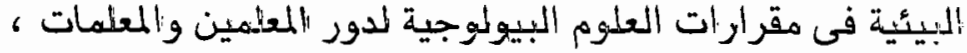

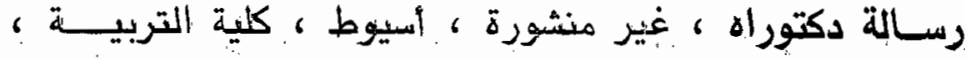

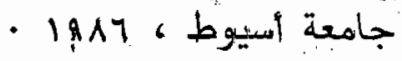

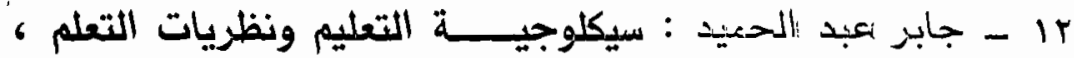

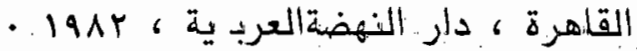

rا ـ جامعة عين شمس : كلية التربية تقسم الصحة النفسية ، بيانات

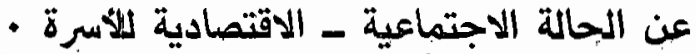

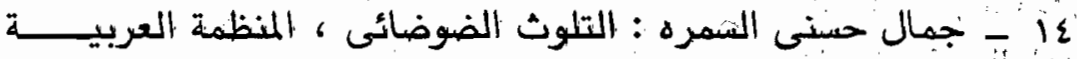

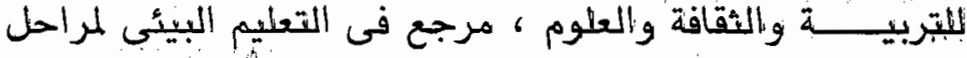

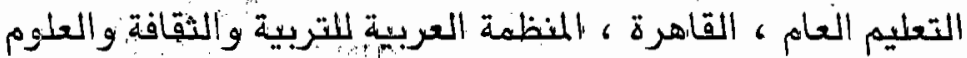

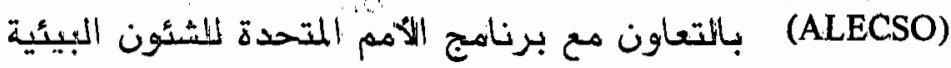
- 19V7:6, (UNEP)

10 - ـ جمال حسنى السمرة : تلوث الهواء ، المنظمة العربية للتربيــــة

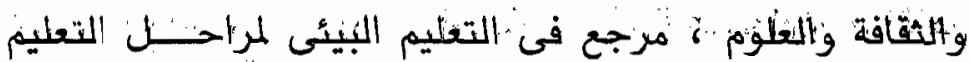

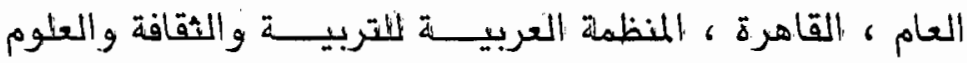
(ALECSO) - 19Vi ، (UNEP)

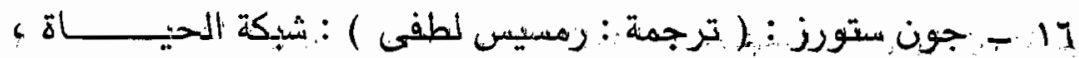

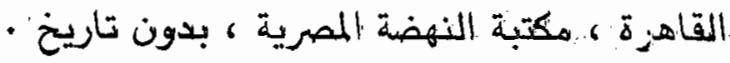




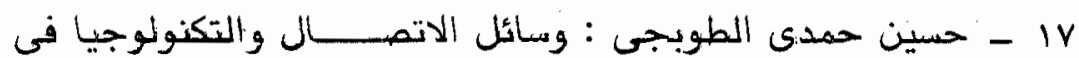

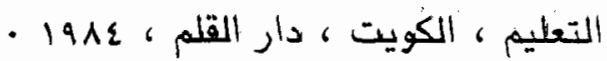

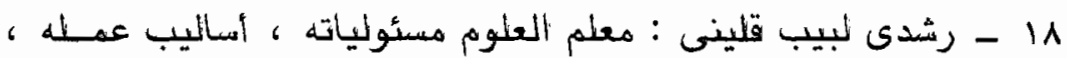

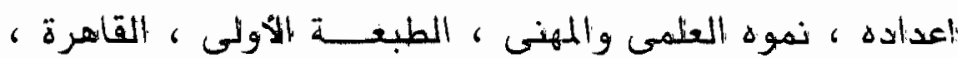

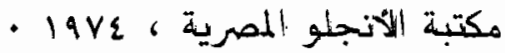

19 - رشدى لبيب قلينى : نمو المفاهيم العلميـــة ، القاهرة ، مكتبة

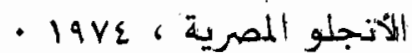

• - ـ روبرت لافون ( ترجمة : نادية القبانى ) : التلوث ، القاهرة ،

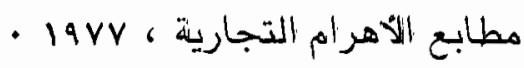

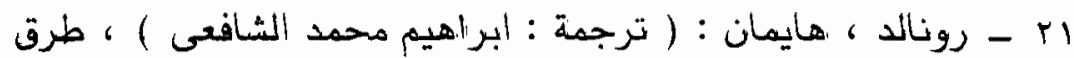

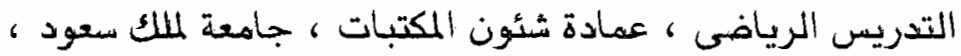
- 1914

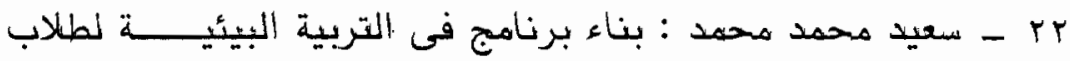

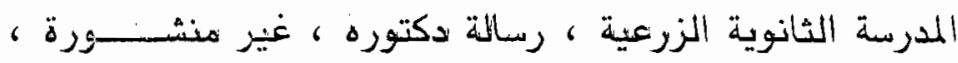

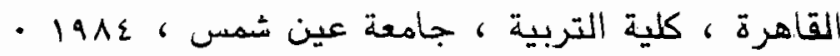

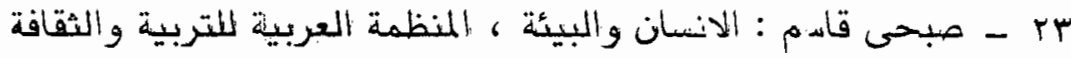

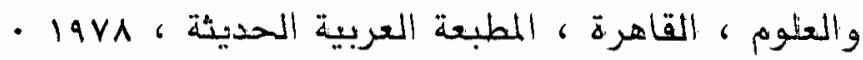

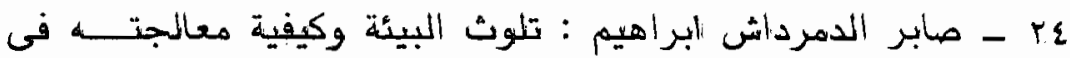

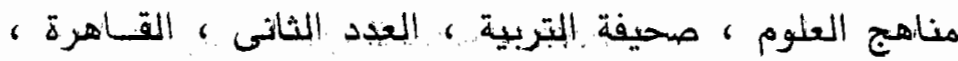

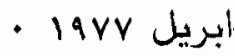

ro ـ صبرى الدمرداش ، فوزى أحمد الحبشى : الاتجاهات البيئية

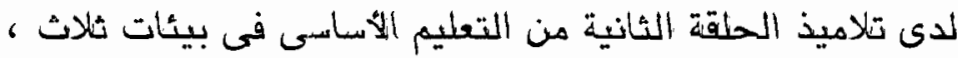

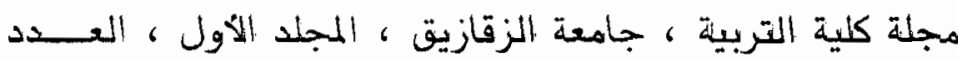

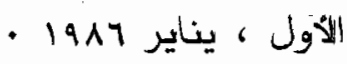




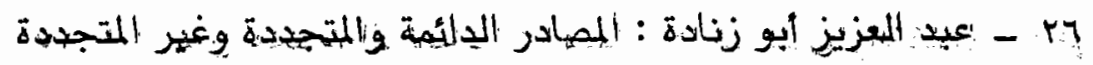

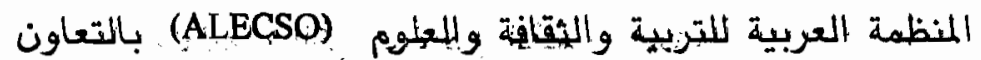

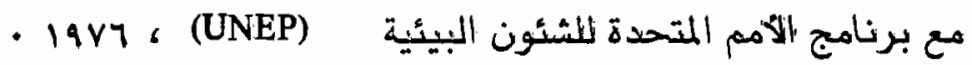

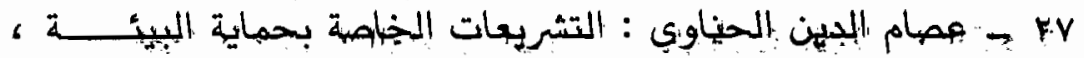

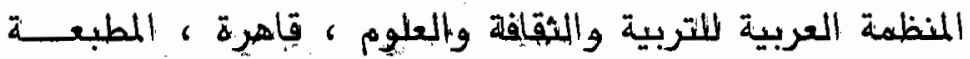

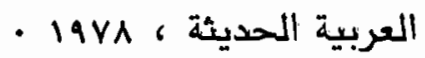

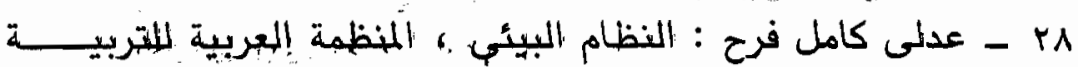

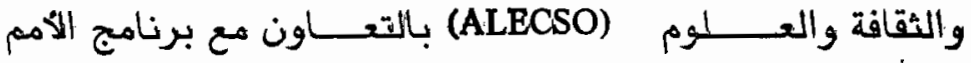

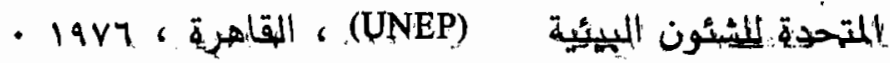

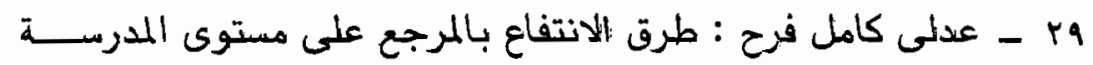

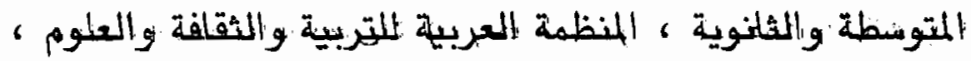
(ALECSO). • ( lavy ، القاهج ، (UNEP)

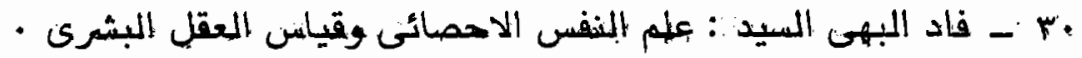

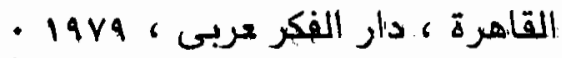

ابr - فؤاد مليمان قلادة : الأأهداف التربوية والتقويم ، القاهرة ، دمار

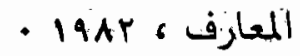

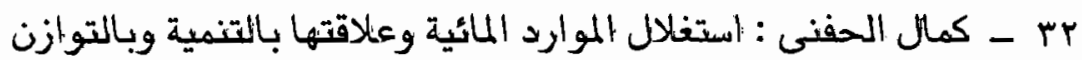

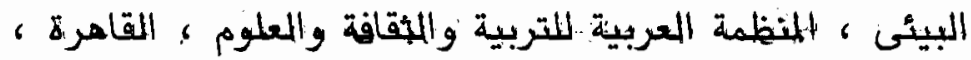

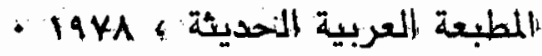

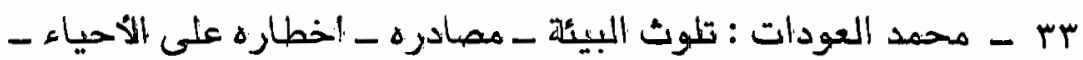

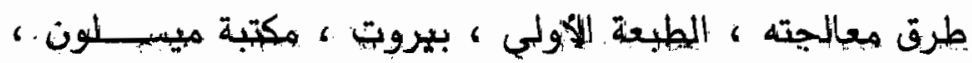
- lava

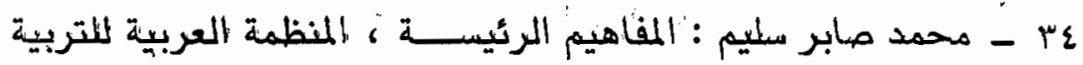
والثقافة والعلوم هابر ملمع : 


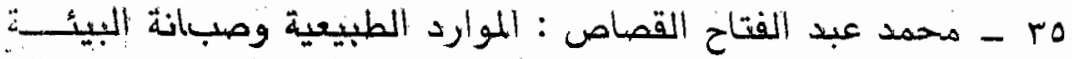

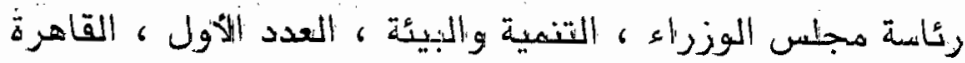

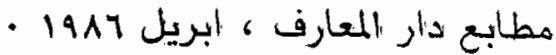

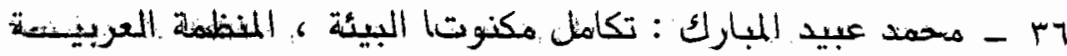

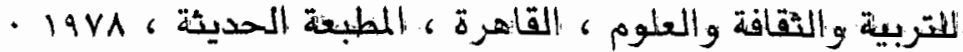

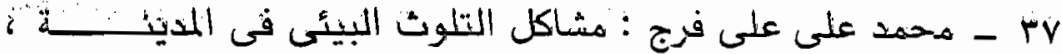

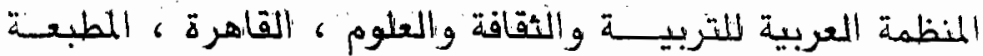
- العزبية الحديئة ، 19va

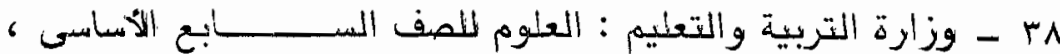

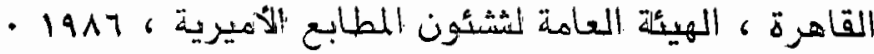

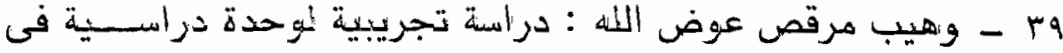

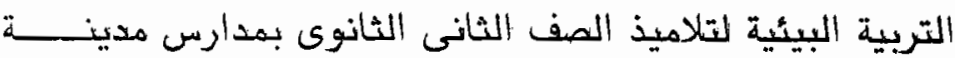

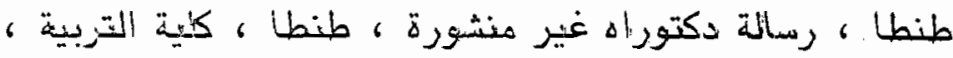

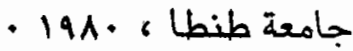

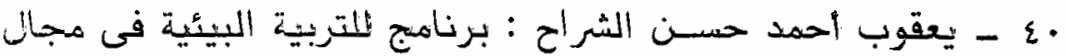

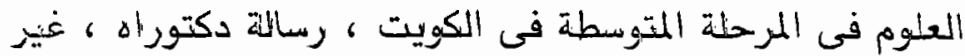

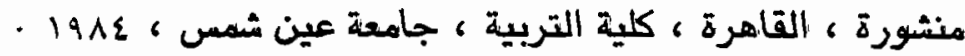

4.1 - B. Daniele and J. Fraser. Student Perceptions of Preferred Classroom learning Envirenment. The Journal of Educational Research. Vo. 80, N, September - October 1986.

42 - B.R. Andersson. H. Lucht. Eummaries. ean Journal of Science Education. Vol : I, No : 2. April June 1979.

43 - Chen Michael and Fresko Barbara. The Interaction of School Environment and Student Trait Educational Research. The Journal of the National Foundation for Educational Research. Vo : 20, No. February 1978. 


\section{THE EFFECTIVENESS OF THE USE OF ENVIRONMENTAL APPROACH IN DEVELOPING SOME FACTS AND CONCEPTIONS OF SEVENTH GARDE STUDENTS OF BASIC EDUCATION \\ Dr. El-Sayed Shehata Mohamed}

\section{Aims of the study :}

1 - Planning programmes on environmental education for seventh grade students of basic education.

2 - The use of environmental approach in teaching suggested programmes.

3 - Finding out the effectiveness of the use of environmental approach in developing some facts and conceptions included in the suggested programme.

\section{Questions :}

1 - What is the suggested programme in environmental education for seventh students of basic education?

2 -- How can environmental approach be used in teaching suggested programmes?

3- How far is the use of environmental approach effective in developing some facts and concepts ?

\section{Results :}

This study has reached the rollowing result :

"The use of environmental approach leads to developing some facts and conceptions that the people selected as samples haves". 